\title{
Elektromos és kézi fogkefék hatékonyságának összehasonlítása az orális prevencióban
}

\author{
Irodalmi áttekintés, systematic review, meta-analízis
}

DR. NAGY PÁL, DR. KÖVÉR KRISZTIÁN, DR. GERA ISTVÁN, DR. HORVÁTH ATTILA

\begin{abstract}
Háttér: A dentális plakk eltávolítása fontos szerepet játszik a szájüregi egészség fenntartásában. Ezen cél eléréséhez számos elektromos és kézi fogkefét fejlesztettek ki, ám még a mai napig is eltérő vélemények és kutatási eredmények látnak napvilágot az említett eszközök prioritásának vizsgálata során.

Célkitüzés: Az elektromos és kézi fogkefék összehasonlítása parodontális paraméterek és biztonságosság alapján.

Vizsgálati módszer: A MEDLINE és EMBASE (2014 májusáig bezárólag) elektronikus adatbázisainak kulcsszavak segítségével történő szűrése a témába illő közlemények felkutatásához. A beválogatási kritériumok az alábbiak voltak: randomizált kontrollált klinikai vizsgálat, felnőtt korú populáció, legalább 15 maradó fog jelenléte. A fogorvos vagy szájhigiénikus általi tisztítást, illetve a tükörszimmetrikus vizsgálatokat kizártuk. Az elsődleges vizsgálati paraméterek a plakk és gingivális indexek változásai, míg a másodlagosak a klinikai szondázási mélység (PPD) változása, a fogkefék biztonságossága és a publikációk minőségi értékelése voltak. Az intervenciós hatás nagyságának kifejezésére a standardizált átlagos különbséget (SMD) használtuk 95\%-os konfidencia intervallummal, random hatás modell segítségével.

Eredmények: Az elektronikus keresés 173 találatot adott, melyből végül 21 tanulmány 1500 résztvevő alannyal került beválogatásra a meta-analízisbe. Mind az elektromos, mind a manuális fogkefék biztonságosnak bizonyultak komoly lágy- és keményszöveti mellékhatások nélkül. Az elektromos fogkefék általánosságban hatékonyabban távolították el a lepedéket $(-9 \%)$ és csökkentették a gingivitist $(-6 \%)$ és fogkőképződést. A plakk indexnél az SMD $-0,40(95 \% \mathrm{Cl}$ : $-0,95,-0,16)$, míg a gyulladásos indexeknél $-0,29(95 \% \mathrm{Cl}:-0,56,-0,03)$ volt az elektromos fogkefe javára. A PPD csökkenésében nem volt szignifikáns különbség. Az elektromos fogkeféket tovább osztva müködési elv alapján elmondható, hogy az oszcilláló-rotáló (pulzáló), a szónikus, illetve az ultraszónikus fogkefék lepedék-eltávolítása szignifikánsan jobb volt, mint a kézi fogkeféké. Ugyanez már nem mondható el az ellen-oszcilláló és az ionizáló fogkefékről. A vizsgálatok minőségi értékelése rávilágított, hogy a publikációk nem teljesen részrehajlásmentesek, ezért egyetlen tanulmány sem felelt meg a legmagasabb minőségi kritériumoknak.

Következtetések: A vizsgált oszcilláló-rotáló és rezgő fogkefék statisztikailag hatékonyabbak a kézi fogkeféknél, bár ezen előny klinikai relevanciája kevéssé ismert. Megfelelően instruált és motivált pácienseknél az elektromos fogkefe előnye megszúnik, ami megerősíti az egyénre szabott szájhigiénés oktatás jelentőségét. Továbbá a vizsgálatok nagyfokú metodikai heterogenitást mutatnak, így a statisztikai feldolgozásából nyert klinikai következtetéseket óvatosan kell kezelni.
\end{abstract}

Kulcsszavak: elektromos és kézi fogkefe, plakk és gingivális index, systematic review, meta-analízis

\section{Bevezetés}

A dentális plakk elsődleges etiológiai tényező az ínygyulladás kialakulásában. Löe és mtsai klasszikus experimentális vizsgálata óta tudjuk, hogy teljesen ép gingivával rendelkező, egészséges fiatalokban ínygyulladás fejlődik ki, ha felhagynak a fogmosással. A szájhigiénia professzionális helyreállítása és az alapos fogmosás újrakezdése után a gingivitis meggyógyul, az íny egészsége helyreáll [Löe 1965]. A dentális plakk egyben szükséges, de nem elégséges oki tényező a gingivitis parodontitisbe történő progrediálásában. A supragingivális plakk-értékek és a parodontális tapadásveszteség közötti kapcsolat gyenge, a kettő közötti viszony komplex, és sok, mai napig már felfedezett és még mindig nem teljesen tisztázott rizikótényezők tehetők felelőssé a gyulladásos folyamat mélyre terjedéséért és az alveoláris csontpusztulásért [Page 1997, Kornman 2008].

A caries kialakulásában is fő oki tényező a bakteriális biofilm, habár a bizonyítékok a szájhigiénia és a caries kapcsolatában nem mindig egységesek [Addy 1986]. Ha fluoridos fogkrémmel mosunk fogat, akkor a caries prevenciós hatás bizonyított, ám ez inkább a fluorid hatásának, mintsem önmagában a fogmosásnak tulajdonítható [Chesters 1992]. Az a tény azonban egyértelmú, hogy a jó szájhigiénia elengedhetetlen eszköz a parodontális és cariológiai megbetegedések prevenciójában [Axelsson \& Lindhe 1981, 1991, 2004; Tinanoff 2002; Merchant 2002]. Általánosságban ugyan elmondható, hogy a mechanikai tisztítás potenciálisan elegendő az érett 
szupragingivális plakk kontrollálásában; azonban irreális bárkitől teljes plakkmentességet elvárni. A hatékony fogmosást ugyanis sok tényező befolyásolja. Alapvetően meghatározó a páciens kézügyessége, de nagyon fontos a motiváció és az elméleti felkészültsége is.

A gyártók ezen faktorok módosító szerepének minimalizálása érdekében kezdték az 1960-as évek elején kifejleszteni az első elektromos fogkeféket, melyeknek mozgásai a kézi fogkefék körkörös, vagy a sörték laterális elmozdulásait utánozták [Elliott 1963]. Az évek során egyre inkább a körkörös mozgásúak kerültek előtérbe [van der Weijden 1993a], de megjelentek a magas frekvencián vibráló elektromos fogkefék is [Terezhalmy 1995]. Az utóbbi évtizedekben ezen eszközök egyre szélesebb körben terjedtek el, és váltak egyre elfogadottabbá [Stålnacke 1995]. A kézi és elektromos fogkefék hatékonyságát összehasonlító tanulmányok eredményei eltérők. Sok szerző szerint az elektromos fogkefék (főleg az oszcilláló-rotáló típusúak) rövid- és hosszú távú vizsgálatokban hatékonyabban csökkentették a plakkot [Johnson \& Mclnnes 1994, Rapley \& Killoy 1994, Stoltze \& Bay 1994, Van der Weijden et al. 1994, 1998, Warren \& Chater 1996, Ho \& Niederman 1997, Saxer \& Yankell 1997, Cronin et al. 1998, Day et al. 1998], redukálták a gingivitist [Barnes et al. 1993, Stoltze \& Bay 1994, Van der Weijden et al. 1994, 1998, Warren \& Chater 1996, Ho \& Niederman 1997, Cronin et al. 1998] és a tasakmélységet, mint manuális társaik. [Ho \& Niederman 1997]. Más tanulmányok ezt a különbséget nem tudták alátámasztani [Cronin 2001, Versteeg 2006, McCracken 2004, Renton-Harper 2001]. Az elektromos fogkefék biztonságosságát a lágyszövetek egészsége szempontjából egyenértékűnek találták a kézi társaikéhoz hasonlítva [Danser 1998, Dimosthenis 2001]. Jogosan merül fel tehát a fogorvosokban a kérdés, hogy a gyártók sokszor elfogult ajánlásait figyelmen kívül hagyva, és a bizonyítékokon alapuló orvostudományra alapozva, mit ajánlhatunk pácienseinknek inkább, az elektromos vagy a kézi fogkefét?

Napjaink legmagasabb evidenciaként elfogadott publikációs formáját az adott témában készített systematic review-k képezik. A systematic review készítésének célja, hogy a magas minőségű, többnyire randomizált kontrollált vizsgálatokból kapott kutatási eredményeket öszszegezze és széleskörüen, illetve naprakészen közölje transzparens módszerek segítségével, miközben a hibák, részrehajlások minimalizálására törekszik [Needleman 2002]. Mindemellett a publikáció stílusa jelentősen különbözik a hagyományos, elbeszélő stílusú cikkekétől, inkább az eredményekre, következtetésekre koncentrál, hogy ezáltal is segítse a klinikai döntéshozatalt. Irodalmi összegzések léteztek korábban is, azonban a systematic review egy zárt, strukturált protokoll szerint megszerkesztett összegzés, ami a protokoll követése által válik objektívvé, és teszi lehetővé az irodalomban fellelhető hibák kiszűrését.

Ilyen systematic review, ami meta-analízist is magában foglal (azaz különböző vizsgálatok számszerüsített eredményeit statisztikailag feldolgozó és összehasonlító úgynevezettn. forest plot táblázatot is tartalmaz), legjobb tudomásunk szerint még nem lett a hazai zászlóshajó Fogorvosi Szemlében publikálva.

\section{Célkitúzések}

Célul tűztük ki az elektronikus adatbázisokban fellelhető irodalmi adatok felhasználásával összehasonlítani az elektromos és kézi fogkefék hatékonyságát a felnőtt lakosság körében. Választ kerestünk arra is, hogy van-e eltérés a különböző elven múködő elektromos fogkefék hatásossága között, továbbá azt is vizsgáltuk, hogy a páciens alapos instruálása hogyan befolyásolja az eszközök hatékonyságát.

\section{Módszerek és eszközök}

\section{Beválogatási kritériumok}

Tanulmányunkba azokat a randomizált, kontrollált klinikai vizsgálatokat válogattuk be, amelyek elektromos fogkeféket hasonlítottak össze kézi fogkefékkel. A különböző elektromos vagy több kézi fogkefét egymással szembe állító tanulmányokat kizártuk. A „cross-over” típusú vizsgálatok igen, de a „split-mouth” típusú vizsgálatok nem kerültek beválogatásra, mivel ezek kellőképpen nem reprezentálják a mindennapos otthoni használatot. Az egyszeri intervenciós vizsgálatok és azok, ahol a szájhigiénés beavatkozásokat szék mellett dentálhigiénikus vagy fogorvos végezte, szintén nem kerültek beválogatásra.

A beválasztott közleményekben a teszt- és a kontrollcsoportokban 18 év feletti, mentálisan és fizikálisan ép alanyok szerepelhettek, akiknél nem merülhetett fel az otthoni egyéni szájhigiénét befolyásoló tényező. Az önkénteseknek a bölcsességfogakat leszámítva min. 15 maradó foggal kellett rendelkezniük. A dohányzás, terhesség, fogszabályozó készülék, illetve fennálló fogágybetegség nem volt kizárási kritérium.

Az alanyok otthoni szájápolásuk során használhattak egyéb eszközt (fogselyem, interdentális kefe), kivéve a kémiai profilaxist (szájfertőtlenítők). Bármilyen típusú elektromos és kézi fogkefe képezhette a vizsgálat tárgyát. Az előbbi eszközöknél működési elv alapján 6 csoportot állítottunk fel:

A. Szónikus: a sörték laterális elmozduló mozgást végeznek $250 \mathrm{~Hz}$ körüli frekvenciával, mely 3-4 mm amplitúdójú kilengést a fogkrém-nyál oldatban mikrocirkulációt vált ki, ami hozzájárulhat a lepedék feloldásához. (1.a ábra)

B. Ellen-oszcilláló: a 2 sorban elhelyezett szomszédos sörtecsomók (ált. 6-10 darab) egymástól függetlenül váltakozó irányba forognak. (1.b ábra)

C. Oszcilláló-rotáló (pulzáló): a sörtéket tartalmazó fej váltakozva rotál $60^{\circ}$ kilengéssel egyik, majd másik irányba. Ide soroltuk ennek továbbfejlesztett 3D-s 


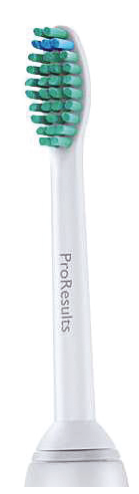

1. ábra:

a) szónikus;

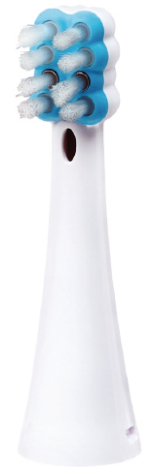

b) ellen-oszcilláló;

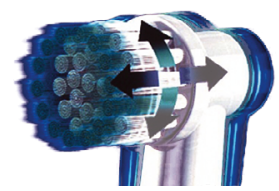

c) oszcilláló-rotáló;

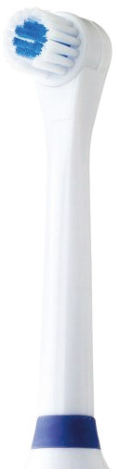

d) körkörös;

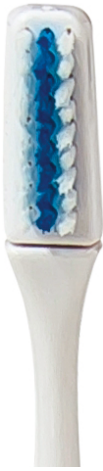

e) ultraszónikus;

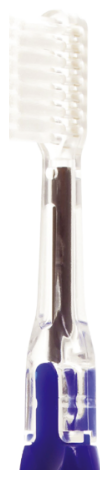

f) ionizáló fogkefék változatát is, ahol a fej még pulzáló mozgást is végez merőlegesen az előző mozgáshoz képest. A hibrid fogkefék is ebbe a csoportban kerültek besorolásra, ahol az oszilláló-rotáló fej mellett még egy további kiegészítő fej is található (pl. előre-hátra transzlációs mozgással). (1.c ábra)

D. Körkörös: a fogkefe feje csak egy irányba végez forgómozgást. (1.d ábra)

E. Ultraszónikus: a sörték ultrahang tartományban (>20 kHz) vibrálnak, amely szintén mikrocirkulációt vált ki a fogfelszínen. (1.e ábra)

F. Ionizáló: Az elemi sörteszálak elektromosan töltöttek. Múködésük alapja a fogfelszín elektromos polaritásának megváltoztatása révén a plakk kötődésének megakadályozása. (1.f ábra)

A sörteszálak elosztása, orientációja, mérete, formája és keménysége, illetve beépített időmérő jelenléte nem befolyásolta az előbbi csoportok meghatározását, és a további vizsgálat tárgyát sem képezte.

Az elsődleges vizsgálati paraméter a plakk és gingivális index értékeinek változása volt. A másodlagos paraméterek a fogkő indexek és tasakmélység változások, illetve az eszközök biztonságos használatának, azaz esetleges káros mellékhatásának kiértékelése voltak.
Amennyiben egy vizsgálat több elektromos eszközt értékelt, úgy azt mi is külön analizáltuk, illetve az egyénre szabott szájhigiénés oktatás befolyásoló szerepét is értékeltük.

\section{Keresési stratégia}

A keresést igyekeztünk kiterjeszteni az összes ide vonatkozó randomizált kontrollált klinikai vizsgálatra. $A z$ eredeti publikációk felkutatásához elektronikus adatbázisokat használtunk. A MEDLINE (1966-tól 2014 májusáig) és EMBASE (1980-tól 2014. májusig) adatbázisainak keresése kulcsszavak segítségével történt, melyeknek alapját a "Cochrane Sensitive Search Strategy for RCTs" képezte (Cochrane Reviewers' Handbook). Nyomtatott folyóiratokból ugyanakkor „kézi keresést” nem végeztünk. A részletes keresési stratégia az I. számú táblázatban található.

\section{Adatgyüjtés és analízis}

A közleményekből az összes releváns információ extrahálása egy előre elkészített excel táblázatba történt, mely az alábbi föbb kategóriákat tartalmazta:

1. A tanulmányok általános karakterisztikája (bibliográfiai adatok, alanyok száma stb.)

2. Minőségi értékelés (randomizáció, kalibráció, masz-

Keresési algoritmus a MEDLINE adatbázisában magyarra fordítva (A zárójelben lévő számok a találati csoportokat jelölik, a táblázatban lévő definíciók pedig a keresési kulcsszavakat.)

\begin{tabular}{|l|l|l|}
\hline \multicolumn{1}{|c|}{ Fogkefe fajtája (1) } & \multicolumn{1}{c|}{ Alkalmazott index (2) } & \multicolumn{1}{c|}{ Mellékhatások (3) } \\
\hline Kézi fogkefe (vagy) & Plakk index (vagy) & Kemény szöveti trauma (vagy) \\
\hline Elektromos fogkefe (vagy) & Fogkő index (vagy) & Lágy szöveti trauma (vagy) \\
\hline Oszcilláló-rotáló fogkefe (vagy) & BOP (vagy) & Ínyrecesszió (vagy) \\
\hline Ultraszónikus fogkefe (vagy) & Gingivális index (vagy) & Gingiva abrázió (vagy) \\
\hline Szónikus fogkefe (vagy) & Interdentális penetráció & Traumatizáció \\
\hline lonizáló fogkefe & & \\
\hline
\end{tabular}

(1) ÉS (2) $=(4)$

(1) ÉS (3) = (5)

(4) VAGY (5) = (6)

A (6). csoportot limitáltuk humán randomizált kontrollált klinikai vizsgálatra. 
kolás, finanszírozás, beválogatás és kizárás, statisztikai analízis, kiindulási homogenitás stb.)

3. Anyag és módszer (teszt- és kontroll-eszközök, instrukciók, tanulmány jellege, vizsgált indexek)

4. Eredmények (indexek változásai, szignifikancia, mellékhatások, megjegyzések)

A tanulmányok minőségi kiértékelése során több tényezőt is figyelembe vettünk. A randomizációt akkor értékeltük megfelelőnek, ha az elosztás jellege közlésre került, és megfelelt a CONSORT irányelveknek (http://www. consort-statement.org/). A maszkolást (vaksági vizsgálat) néztük mind a vizsgáló (indexet regisztráló), mind a statisztikus személyére vonatkozóan. Ez akkor volt elfogadható, ha vizsgáló nem tudja, hogy az önkéntes a teszt- vagy a kontroll csoportba tartozik-e. A kalibráció egy klinikus többszöri mérései közötti (intraexaminer error), vagy több vizsgáló mérései közti (interexaminer error) megbízhatóságot kifejező statisztikai módszer. A finanszírozás szempontjából a vizsgálat szponzoráltnak tekinthető, ha a kutatáshoz anyagi támogatást, vagy a teszteszközöket a gyártó bocsátotta rendelkezésre. Ha nem volt erre vonatkozó információ, akkor tisztázatlan a finanszírozás, míg csak akkor tekinthető szponzorálatlannak, ha erre vonatkozó kijelentést tettek a szerzők. Vizsgáltuk a tanulmányok kezdetekor fennálló homogenitást, azaz a teszt- és kontrollcsoportok közötti kiindulási paramétereket korra, plakk és gingivális indexre, dohányzásra és medikációra való tekintettel. Amennyiben ezek között szignifikáns különbség mutatkozik, úgy ez befolyásoló faktor lehet a végeredményre nézve. Végezetül minőségi szintjelző lehet az egyes publikációk statisztikai feldolgozása. Kíváncsiak voltunk a statisztikai mérés választásának, leírásának helyességére, illetve a minta nagyságbeli kalibrációjából fakadó erősség jelenlétére.

A minőségi kiértékeléssel a tanulmányok részrehajlását kívántuk megvizsgálni, amelyek az eredmények valósságát, hitelességét befolyásolhatják. Az előbb említett főbb minőségi kritériumokat táblázatba foglaltuk (III. táblázat), és ezek alapján minden tanulmányt a Cochrane Handbook for Systematic Reviews of Interventions 5.0.2 ajánlása szerint egy 3-as skálán osztályoztuk [Higgins 2009]. Részrehajlás (bias) szempontjából alacsony rizikójú a vizsgálat, ha a minőségi kritérium egyértelmúen meghatározott. Tisztázatlan rizikójú, ha a cikk nem tesz említést, vagy a leírás alapján a kritérium nem elbírálható, vagy nem teljeskörü. Magas rizikójú, ha a közlemény nem tesz eleget az előírásoknak. Az összes minőségi kritériumot figyelembe véve a tanulmányokat az alábbi 3 kategóriába soroltuk a részrehajlás rizikója alapján:

- Magas rizikójú: ha 2 vagy annál több kritérium magas és legalább van 1 tisztázatlan rizikójú.

- Közepes rizikójú: ha maximum 2 kritérium magas, vagy 1 magas és még legalább 1 tisztázatlan rizikójú.

- Alacsony rizikójú: ha maximum 2 tisztázatlan rizikójú kritérium található a vizsgálatban.
Az irodalomkutatás során sok különböző plakk és gingivális indexszel találkoztunk. Voltak olyan közlemények is, amelyek több indexet regisztráltak. Ezekben az esetekben egy korábbi összefoglalóban [Heanue 2003] felállított hierarchia szerint választottunk indexet, hiszen egy tanulmány csak egy adattal szerepelhet az analízisben. A rangsort az index használati gyakorisága és egyszerüsége alapján határoztuk meg. Ezek alapján plakk-mérés esetén, ha lehetett, a Turesky által módosított Quigley-Hein indexet [Turesky 1970], míg a gingiva állapota esetén a Löe és Silness indexet [Löe \& Silness 1963], illetve annak hiányában a szondázási ínyvérzést vettük alapul [Ainamo 1975]. Minden esetben megpróbáltunk teljes szájmérési eredményeket alapul venni, ahol csak részleges mérési eredmények voltak, ott szenzitivitási vizsgálatot csináltunk, hogy ellenőrizzük befolyásukat az összefoglalóra nézve.

Különböző plakk és gingivális indexek hasonló koncepció alapján és magas korrelációval mérnek, de különböző skálákon. Az eltérő mértékegységekben vizsgált hatások azonos skálára hozásának érdekében használjuk az úgynevezett hatásnagyságot (effect size), amely a kezelési csoportok átlagai közti különbségnek és az adatok szórásának a hányadosa, egyfajta standardizált hatás, dimenzió nélküli szám. A meta-analízis a hatásnagyság mérésénél a standardizált átlag különbségét (standardised mean difference: $S M D$ ) használja a 95\%-os konfidencia intervallummal $(C l ; p=0,05)$ [Deeks 2001]. Szükséges, hogy meg tudjuk becsülni az egyik eszköz prioritásának nagyságát a másik felett, és mivel az SMD-k klinikai tartalommal nem bírnak, ezért át kell konvertálni őket ekvivalens értékkel bíró klinikai indexekké. Ehhez vissza kell nyúlnunk az egyik olyan vizsgálat SMD értékéhez, amely hasonló átlagot kapott, mint a mi meta-analízisünk, és ennek a cikknek klinikai értékei alapján értékelhetjük a mi eredményeinket. Tekintettel arra, hogy az egyes tanulmányok között a hatásnagyságot vizsgálva valódi differenciák lesznek, és a meta-analízissel a hatások eloszlásának átlagát próbáljuk megbecsülni, ezért a számításokat a randomhatás modell alapján végeztük [Borenstein 2009]. A tanulmányokból extrahált numerikus adatokat a Review Manager 5.2 szoftverbe (CochraneTech, London, UK) tápláltuk be, mely a SMD számolása után fasor-ábra (forest plot) diagramokkal szemléltette és súlyozva öszszegezte a kapott eredményeket. Mivel a szoftver táblázatainak nyelvét sajnos nem lehet módosítani, így azok az eredeti angol nyelven kerültek jelen közleményünkbe.

A témakörben keresztezett (cross-over) és paralellelcsoport típusú vizsgálatokkal találkoztunk. A két heterogén protokoll adatainak kombinálására az Elbourne és mtsi [Elbourne 2002] által leírt technikát használtuk.

Egyes tanulmányok egyszerre több típusú elektromos fogkefét is vizsgáltak a tesztcsoportokban. Mivel a meta-analízisben egy közlemény csak egy adattal képviselhette magát, hogy ne torzítsa el a végeredményt, ezért ezekben az esetekben az alábbiak szerint jártunk el. Az elektromos fogkefék összesített vizsgálatánál 
a publikációban szereplő, különböző típusú eszközök ide vonatkozó index-értékeit (mean $\pm \mathrm{SD}$ ) súlyozottan átlagoltuk (a tesztcsoportok létszámától függően). Amikor az elektromos fogkeféket múködési elvek alapján hasonlítottuk össze, akkor természetesen mindig a tanulmány adott típusú teszteszközének releváns index értékét vettük alapul.

Az eredmények kiszámítása után úgynevezett szenzitivitási analízist végeztünk, melyre azért volt szükségünk, hogy kiderítsük: a vizsgálatunk tervezete, illetve a minőségi szempontoknál használt feltételezések befolyásolták-e a végeredményeinket. Ennek érdekében a tesztet a meta-analízisek megismétlésével végeztük a következő esetekben: ahol teljes szájindexet használtak, ahol a randomizáció a megfelelő kritériumok alapján történt, ahol megfelelő volt a maszkolás, ahol a kutatást a gyártó nem szponzorálta, ahol teszt- és kontrollcsoportok homogének voltak (magas minőségi kritériumok). Végül külön megnéztük a követéses (follow-up) vizsgálatok eredményét, ami megmutatja, hogy a nagyobb mintaszámmal dolgozó „cross-over” vizsgálatok menynyire torzíthatják az össz hatásnagyságot. A szenzitivitási analízist csak az összes típusú elektromos fogkefét vizsgáló összehasonlítás esetén végeztük, mert ott volt egyedül nagy számú tanulmány, ahol szignifikáns eredményt is kaptunk plakk- és gingivális index tekintetében (lásd 1. Összehasonlítás: 1.1 és 1.2 eredmények).

\section{Eredmények}

\section{Tanulmányok leírása}

Az elektronikus keresés lefuttatása után 173 releváns publikációcímet találtunk. Az alábbi folyóiratok adták a legtöbb találatot: Journal of Clinical Periodontology; Journal of Periodontology; American Journal of Dentistry; Journal of Clinical Dentistry; Compendium of Countinuing Education in Dentistry. A címek alapján 103 absztraktot értékeltünk, melyek közül a beválogatási és kizárási kritériumok figyelembevételével 79 tanulmányra szükült le a kör. A Semmelweis Egyetem és az UCL Eastman Dental Institute elektronikus folyóirat katalógusát használva 28 közlemény teljes szövegéhez fértünk hozzá.

Négy vizsgálat a tükörszimmetrikus (split-mouth) protokoll miatt nem került beválogatásra [Versteeg 2006; Danser 2003; Quirynen 1994, van der Weijden 1993], további négy publikáció nem közölt statisztikailag feldolgozható adatot (SD hiánya vagy értékek mediánban) [Zimmer 2005, 2002; Ainamo 1997; Haffajee 2001]. Egy közlemény csak a frontfogak labiális felszínén regisztrált, melyet kevésnek találtunk teljes száj-körülményekhez való viszonyításhoz [Erbe 2013]. Ezek átolvasása után végezetül tehát 21 tanulmány (19 teljes cikk és 2 absztrakt) szolgált statisztikailag feldolgozható adattal a meta-analízishez. A vizsgálatok több mint felét (11) Európában [Rosema 2008; Dörfer 2001; McCracken 2004; Renton-Harper 2001; Pizzo 2010; Mantokoudis
2001; Aass \& Gjermo 2000; Heasman 1999; Stoltze \& Bay 1994; van der Weijden 2002, 1994], míg a kisebbik hányadát (10) az Egyesült Államokban végezték [Terézhalmy 2005, 1995; Dentino 2002; Williams 2004; Khocht 1992; Johnson \& McInnes 1994; Moritis 2008; Forgas-Brockmann 1998; O'Beirne 1996; Tritten \& Armitage 1996]. A kvantitatív adattal szolgáló közleményeket 1992 és 2010 között publikálták.

\section{a) Demográfiai karakterisztika}

A beválogatott tanulmányokban szereplő önkéntesek összlétszáma kereken 1500 fő volt. A követés során lemorzsolódott páciensek száma pedig 90 -ig emelkedett (6\%). Három közlemény (14\%) esetén engedélyezve volt a dohányzás mint lehetséges befolyásoló faktor, a többi publikáció nem tett említést erről.

\section{b) Eszközök karakterisztikája}

A közleményekben az alábbi típusú elektromos fogkeféket vizsgálták működési elv szerint csoportosítva (lásd II. táblázat):

A. Szónikus: Sonicare, Sonicare Elite (Sonicare c/o Philips Oral Healthcare, Snoqualmie, WA, USA); Epident (Bausch \& Lomb, Tucker, GA, USA)

B. Ellen-oszcilláló: Interplak (Interplak Conair Corporation, Stamford, CT, USA)

C. Oszcilláló-rotáló (pulzáló): Braun Plak Control, Braun/ Oral B Plaque Remover D5, Braun/Oral B D7, Braun/ Oral B D9, Braun Oral-B Plak Control Ultra, Oral-B Professional Care 8500, Oral-B Triumph Professional Care 9000, Braun Oral-B Plak Control 3D (Braun Oral B Consumer Services, South Boston, MA, USA); Crest Spinbrush Pro (Procter \& Gamble, Cincinnati, $\mathrm{OH}$, USA); Philips HP555, Philips HP 735, Philips Jordan 2-action Plaque Remover HP 510 (Philips Jordan, Veldhoven, The Netherlands)

D. Körkörös: Nem találtunk ide vonatkozó tanulmányt.

E. Ultraszónikus: Ultrasonex (Salton-Maxim, Columbia, MO, USA)

F. lonizáló: Gyártó neve nem volt leközölve.

(A gyártók nevei és címei a jelenlegi állapotot tükrözik, egyes típusokat már nem is forgalmaznak, vagy más lett a gyártó, mint mikor a tanulmány készült.)

\section{c) Mérési eredmények karakterisztikája}

19 közlemény szolgált adattal a plakk index- (kiesések után 1106 a teszt- és 1099 alany a kontrollcsoportban), míg 16 publikáció a gingivális index- (kiesések után 562 a teszt- és 555 alany a kontrollcsoportban) értékek öszszehasonlítása tekintetében. Összesen két fogkő indexet is mérő tanulmányt és 3-3 biztonságosságot és szondázási mélységet mérő tanulmányt tudtunk kiértékelni (III. táblázat).

Plakk- és gingivális index tekintetében 16 publikáció közölt teljes száj-értékeket (ezek közül 5 csak plakk, és 1 csak gingivális indexet), míg három vizsgálat mindkét változó tekintetében csak részleges száj-értékeket közölt. 2 tanulmány a plakkot teljes szájon, míg az íny 
Adattal szolgáló tanulmányok összefoglalása

\begin{tabular}{|l|l|c|c|}
\hline Múködési elv & Közlemény & $\begin{array}{c}\text { Tanulmányok } \\
\text { száma }\end{array}$ & $\begin{array}{c}\text { Összes önkéntesek } \\
\text { kiesettek nélkül }\end{array}$ \\
\hline Szónikus & $\begin{array}{l}\text { Johnson \& McInnes 1994; Khocht 1992; O’Beirne 1996; } \\
\text { Tritten \& Armitage 1996; Moritis 2008 }\end{array}$ & 5 & 378 \\
\hline Ellen-oszcilláló & Khocht 1992* & 1 & 63 \\
\hline Oszcilláló-rotáló (3D) & $\begin{array}{l}\text { Aass \& Gjermo 2000; Dörfer 2001; Heasman 1999; } \\
\text { Mantokoudis 2001; McCracken 2004; Pizzo 2010; Rosema 2008; } \\
\text { Renton-Harper 2001; Dentino 2002; Stoltze \& Bay 1994; } \\
\text { Terézhalmy 2005; van der Weijden 1994; Williams 2004 }\end{array}$ & 13 & 838 \\
\hline Ultraszónikus & Forgas-Brockmann 1998; Terézhalmy 1995 & 2 & 102 \\
\hline lonizáló & van der Weijden 2002 & 1 & 60 \\
\hline
\end{tabular}

* Khocht 1992. évi cikke két különböző működési elvű fogkefét is vizsgált.

III. táblázat

A publikációk minőségi kiértékelése

\begin{tabular}{|c|c|c|c|c|c|c|c|c|}
\hline & Randomizáció & Maszkolás & Kalibráció & $\begin{array}{c}\text { Befolyásoló } \\
\text { faktor }\end{array}$ & $\begin{array}{c}\text { Kezdeti } \\
\text { homogenitás }\end{array}$ & Finanszírozás & $\begin{array}{l}\text { Statisztikai } \\
\text { leírás }\end{array}$ & $\begin{array}{c}\text { Összes } \\
\text { részrehajlási } \\
\text { rizikó }\end{array}$ \\
\hline Aass \& Gjermo 2000 & + & + & + & $?$ & + & - & $?$ & Közepes \\
\hline Dentino 2002 & + & + & + & - & - & - & + & Magas \\
\hline Dorfer 2001 & $?$ & + & + & $?$ & $?$ & $?$ & $?$ & Közepes \\
\hline Forgas-Brockmann 1998 & $?$ & + & + & $?$ & + & - & $?$ & Közepes \\
\hline Heasman 1999. & $?$ & + & + & $?$ & + & $?$ & + & Közepes \\
\hline Johnson \& Mclnnes 1994 & $?$ & + & + & $?$ & + & - & $?$ & Közepes \\
\hline Khocht 1992 & $?$ & + & + & $?$ & + & - & $?$ & Közepes \\
\hline Mantokoudis 2001 & $?$ & + & + & $?$ & + & + & $?$ & Közepes \\
\hline McCracken 2004 & + & + & + & - & + & - & + & Közepes \\
\hline Moritis 2008 & $?$ & + & $?$ & $?$ & $?$ & - & $?$ & Közepes \\
\hline O' Beirne 1996 & $?$ & + & + & $?$ & + & - & $?$ & Közepes \\
\hline Pizzo 2010 & $?$ & + & $?$ & $?$ & $?$ & + & $?$ & Közepes \\
\hline Renton-Harper 2001 & $?$ & + & $?$ & $?$ & $?$ & $?$ & $?$ & Közepes \\
\hline Rosema 2008 & + & + & $?$ & - & - & - & $?$ & Magas \\
\hline Stoltze \& Bay 1994 & $?$ & + & $?$ & $?$ & $?$ & $?$ & $?$ & Közepes \\
\hline Terezhalmy 1995 & $?$ & + & $?$ & $?$ & $?$ & $?$ & $?$ & Közepes \\
\hline Terezhalmy 2005 & $?$ & + & $?$ & $?$ & $?$ & - & $?$ & Közepes \\
\hline Tritten \& Armitage 1996 & + & + & + & $?$ & + & - & $?$ & Közepes \\
\hline Van der Weijden 1994 & $?$ & + & $?$ & $?$ & + & $?$ & $?$ & Közepes \\
\hline Van der Weijden 2002 & $?$ & + & $?$ & $?$ & $?$ & $?$ & $?$ & Közepes \\
\hline Williams 2004 & + & + & $?$ & $?$ & $?$ & - & + & Közepes \\
\hline
\end{tabular}

állapotát csak a „Ramfjord” fogakon vizsgálta. (A részleges száj és Ramfjord fogak értékei lehetnek reprezentatívak a teljes szájra nézve, ennek ellenőrzése a szenzitivitási vizsgálattal történt).

\section{Részrehajlás (bias) vizsgálata}

A randomizáció és az elosztás jellege hat publikáció esetén felelt meg a célokban lefektetett követelményeknek (29\%), míg 15 esetben (71\%) tisztázatlannak ítéltük (III. táblázat). A maszkolás a tanulmányok legnagyobb részében (95\%) megfelelő volt, és csak egy esetben volt tisztázatlan. A méréseket végző személyeknél 11 vizsgálatban történt kalibráció (52\%), míg ez a többi esetben szintén tisztázatlan volt (48\%). A befolyásoló faktorok (dohányzás, gyógyszerszedés) tekintetében legtöbbször (86\%) tisztázatlan körülménnyel, és három közleménynél (14\%) magas rizikót (dohányzás) állapítottunk meg. A teszt- és kontrollcsoport közötti kezdeti homogenitás szempontjából 10 esetben (48\%) volt alacsony a részrehajlás (a csoportok minden szempont szerint homogének voltak), kilenc alkalommal (43\%) tisztázatlan és két ( $9 \%$ ) tanulmányban magas rizikó- 
jú (heterogén csoportok). A finanszírozás kérdésében 12 közlemény esetében ( $57 \%$ ) legalább az egyik eszközt a gyártó bocsátotta rendelkezésre, hét esetben erre nem volt utalás $(33 \%)$, és csak két tanulmánynak nem volt szponzora, vagy részesült független alapítványi támogatásban. A statisztikai leírás szempontjából négy közlemény (19\%) felelt meg a követelményeknek, míg a maradék 17 (81\%) tisztázatlan rizikójú (általában a minta nagyságbeli kalibrációjából fakadó erősség jelenlétének hiánya miatt).

A vizsgált 21 publikáció közül kettő esetében állapítottunk meg tehát magas (Dentino 2002; Rosema 2008), míg az összes többi esetében közepes rizikót a részrehajlásra. Alacsony rizikó követelményének egyik tanulmány sem felelt meg. [Higgins 2009] (III. táblázat).

\section{Az intervenciók hatása}

A továbbiakban csoportonkénti elosztásban közöljük az SMD-ket és azok 95\%-os konfidencia szintjeiből fakadó szignifikáns különbségeket.

1. Az összes típusú elektromos fogkefék hatékonyságát és biztonságát a kézi fogkefékkel szemben öszszehasonlítva (lásd 1. összehasonlítás, 1.1-1.5-ig eredmények).

Az elektromos fogkefék általánosságban, múködési elvtől függetlenül statisztikailag szignifikánsan hatékonyabban távolították el a plakkot és csökkentették az ínygyulladást. A plakk indexek tekintetében az SMD -0,40 $(95 \% \mathrm{Cl}:-0,65,-0,15)$, míg gingivális index vonatkozásában -0,29 (95\% Cl: -0,55, -0,02) volt. Ez a különbség egy körülbelüli 0,22 vagy $9 \%$-os plakk értékcsökkenésnek felel meg a Quigly-Hein Index szerint (van der Weijden 2002-es tanulmányát véve alapul, ahol hasonló SMD szerepelt: 0,43), míg a Löe-Silness gingivális indexnél 0,06 vagy $6 \%$-os redukciót jelent (Tritten \& Armitage 1996 eredménye alapján) az elektromos fogkefék javára (IV-V. táblázat).

Két tanulmány eredményeinek alapján az elektromos fogkefék szignifikánsan hatékonyabban előzték meg a fogkőképződést (VI. táblázat). Három-három publikáció közölt mérhető adatot a fogkefék biztonságosságát és szondázási mélységet csökkentő hatásának tekintetében. Nem találtunk szignifikáns különbséget egyik eszköz javára sem az utóbbi két vizsgált paraméter során (VII-VIII. táblázat).

2. Oszcilláló-rotáló (pulzáló) elektromos fogkefe hatékonyságának és megbízhatóságának összehasonlítása a kézi fogkefével (lásd 2. összehasonlítás, 2.12.3-ig eredmények).

Ebben a múködési elv alapján osztályozott csoportban készült a legtöbb vizsgálat. Tizenkét tanulmány szolgált adattal plakk- és nyolc pedig gingiva index adatokkal.
Eredményeinkben az oszcilláló-rotáló és újabban pulzáló mozgást végző elektromos és a kézi fogkefék plakk eltávolító képességében statisztikailag szignifikáns különbséget találtunk az előbbi javára. Az SMD -0,47 (95\% Cl: $-0,81,-0,12)$ volt (IX. táblázat), mely a QuiglyHein skálán körülbelül 0,27 , vagy $11 \%$-al nagyobb lepedékeltávolító hatásnak felel meg (Cronin 1998 adatai alapján). Érdekes módon ez az előny az íny állapotának javulása terén szignifikánsan nem mutatkozott meg. (A gingivális indexnél SMD $-0,34(95 \% \mathrm{Cl}:-0,79$, 0,11)) (X. táblázat).

A fogkőértékek és a biztonságosság tekintetében az eredmények megegyeznek az 1 . számú összehasonlításban leírtakkal, ugyanis az a pár tanulmány, mely ezeket a paramétereket vizsgálta, kivétel nélkül mind oszcilláló-rotáló fogkefét használt a tesztcsoportban. A szondázási mélység csökkenésének vizsgálata során két tanulmány eredményei alapján nincs szignifikáns különbség a két eszköz között (XI. táblázat).

3. Laterális szónikus rezgőmozgás a kézi fogkefével összehasonlítva (lásd 3. összehasonlítás, 3.1-3.3-ig eredmények).

Négy tanulmány vizsgált plakk- és öt gingivális indexet. A két paraméter esetében a statisztikai analízis nem ugyanazt az eredményt hozta. A plakk esetében a szónikus rezgőmozgást végző elektromos fogkefék szignifikánsan több plakkot távolítottak el a fogfelszínekről, de ez a szignifikáns különbség már nem mutatkozott meg az íny állapotát vizsgáló paraméterek esetében. Az SMD értéke az első esetben $-0,46$ ( $95 \% \mathrm{Cl}:-0,68$, $-0,25)$ volt (XII-XIII. táblázat). Egy tanulmány vizsgálta a szondázási mélység változását ebben a csoportban, és itt sem talált szignifikáns eltérést a két típusú eszköz hatékonyságát illetően (XIV. táblázat).

4. Ultraszónikus, ellen-oszcilláló és ionizáló fogkefék a kézi fogkefével összehasonlítva

Az ultraszónikus, ellen-oszcilláló, valamint az ionizáló fogkefékről csak nagyon kevés számú közleményt találtunk, ezért ezeket csak röviden foglaljuk össze, és a forest plot analízis ábrázolását elhagyjuk.

Ultraszónikus elektromos fogkefék plakk eltávolító hatás terén statisztikailag szignifikánsabban hatékonyabbak voltak, mint kézi társaik (SMD: $-0,46,95 \%$, Cl: $-0,92,-0,01)$. Azonban a gingivális index tekintetében nem volt már szignifikáns különbség a két eszköz között. Az ellenoszcilláló elektromos fogkefékkel foglalkozó egyik közlemény szerint nem volt szignifikáns különbség plakk eltávolító hatékonyságban, sőt a kézi fogkefe hatékonyabban csökkentette az ínygyulladást. Az utóbbi esetben SMD 0,68 (95\% Cl: 0,17, 1,19) volt, ez a Löe-Silness index szerint körülbelül 0,12 , mely $46 \%$-os csökkenés a kézi fogkefe javára. Egy tanulmány közlése alapján nem találtunk statisztikailag szignifikáns különbséget az elektromosan ionizáló és a kézi 
Plakk indexek összehasonlítása (1.1 eredmények)

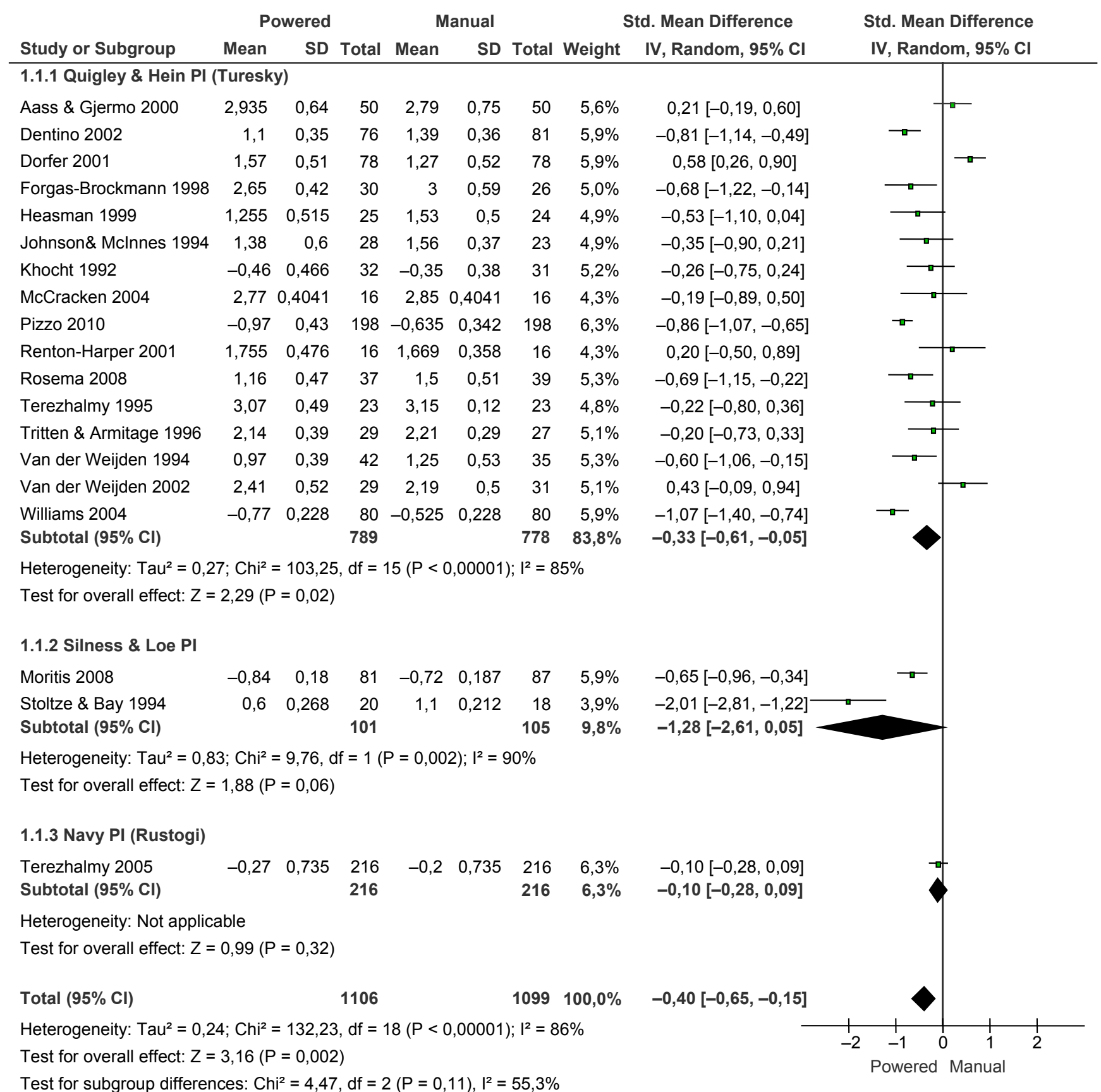


Gingivális indexek összehasonlítása (1.2 eredmények)

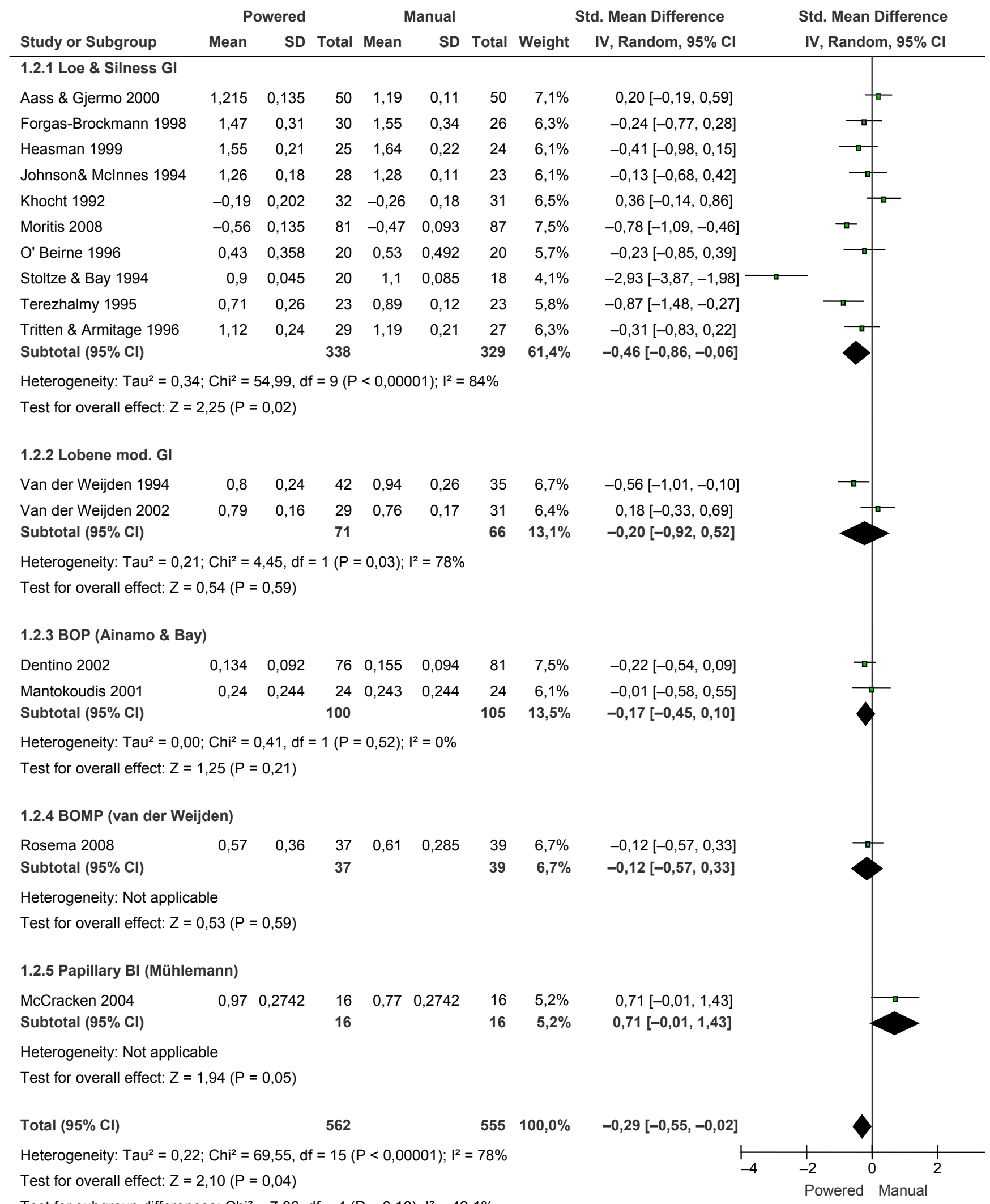

Test for subgroup differences: $\mathrm{Chi}^{2}=7,86, \mathrm{df}=4(\mathrm{P}=0,10), \mathrm{I}^{2}=49,1 \%$ 
Fogkő indexek összehasonlítása (1.3 eredmények)

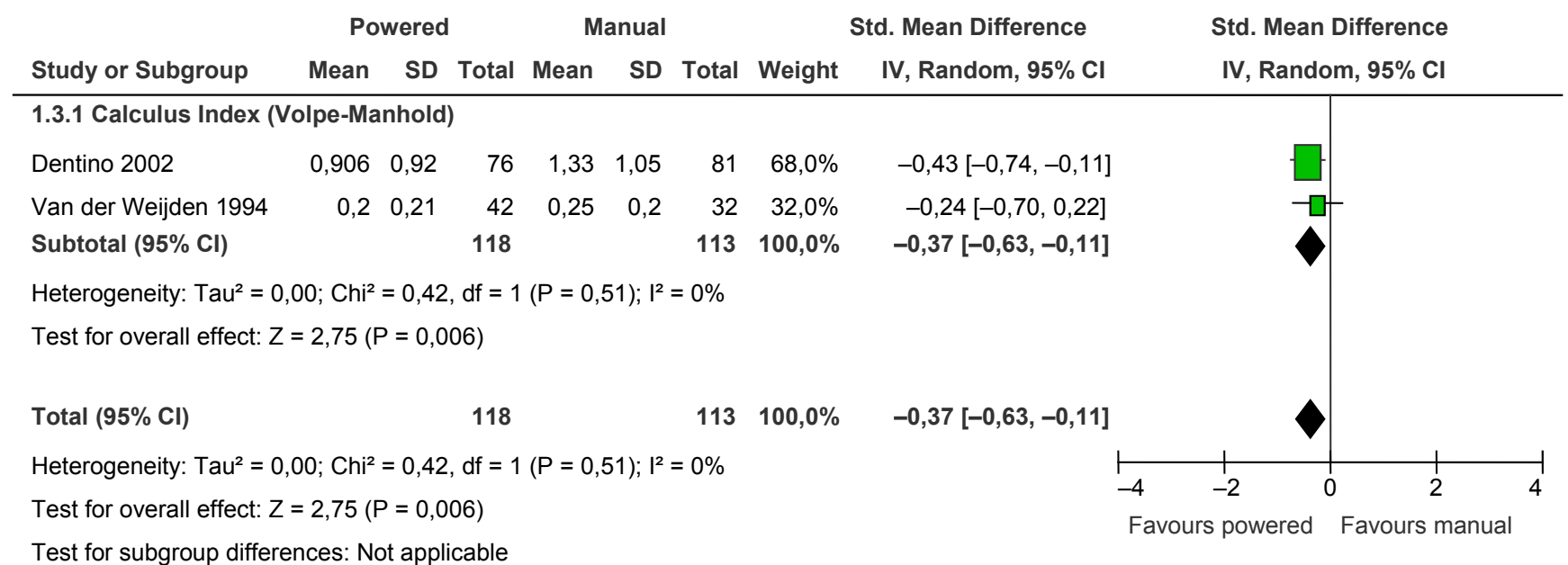

VII. táblázat

Biztonságosság (1.4 eredmények)

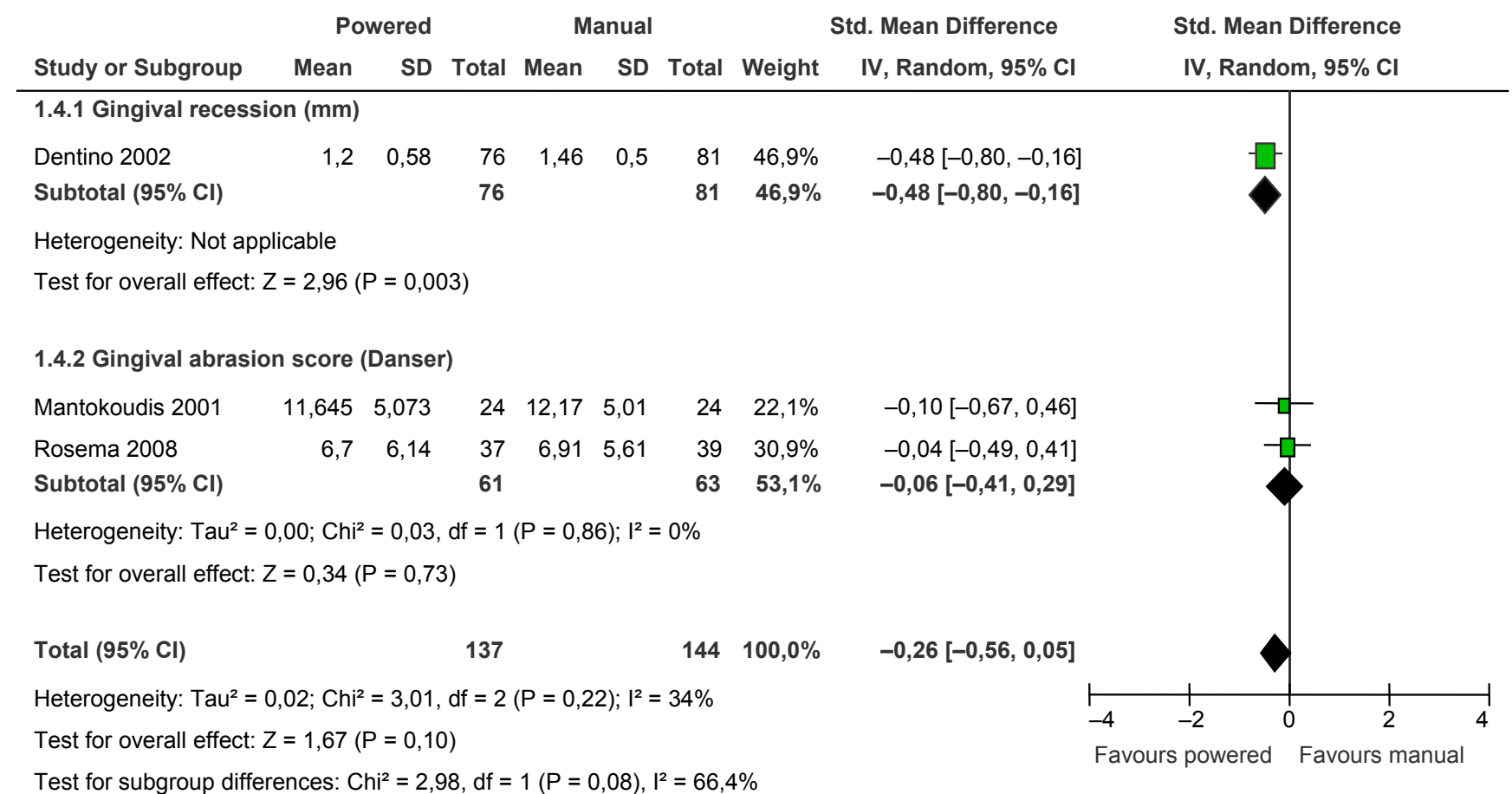


VIII. táblázat

Szondázási mélység összehasonlítása (1.5 eredmények)

\begin{tabular}{|c|c|c|c|c|c|c|c|c|c|}
\hline \multirow[b]{2}{*}{ Study or Subgroup } & \multicolumn{3}{|c|}{ Powered } & \multicolumn{3}{|c|}{ Manual } & \multicolumn{2}{|r|}{ Std. Mean Difference } & \multirow{2}{*}{$\begin{array}{l}\text { Std. Mean Difference } \\
\text { IV, Random, } 95 \% \mathrm{Cl}\end{array}$} \\
\hline & Mean & SD & Total & Mean & SD & Total & Weight & IV, Random, 95\% CI & \\
\hline \multicolumn{10}{|c|}{ 1.5.1 Pocket probing depth $(\mathrm{mm})$} \\
\hline Dentino 2002 & 1,75 & 0,34 & 76 & 1,68 & 0,4 & 81 & $48,6 \%$ & $0,19[-0,13,0,50]$ & \\
\hline McCracken 2004 & 3,07 & 0,3608 & 16 & 2,9 & 0,3608 & 16 & $23,9 \%$ & $0,46[-0,24,1,16]$ & \\
\hline O' Beirne 1996 & 4,33 & 0,402 & 20 & 4,56 & 0,626 & 20 & $27,5 \%$ & $-0,43[-1,06,0,20]$ & \\
\hline Subtotal $(95 \% \mathrm{CI})$ & & & 112 & & & 117 & $100,0 \%$ & $0,08[-0,35,0,52]$ & \\
\hline \multicolumn{10}{|c|}{ Heterogeneity: $\mathrm{Tau}^{2}=0,07 ; \mathrm{Chi}^{2}=4,00, \mathrm{df}=2(P=0,14) ; \mathrm{I}^{2}=50 \%$} \\
\hline \multicolumn{10}{|c|}{ Test for overall effect: $Z=0,38(P=0,71)$} \\
\hline Total $(95 \% \mathrm{Cl})$ & & & 112 & & & 117 & $100,0 \%$ & $0,08[-0,35,0,52]$ & \\
\hline \multicolumn{9}{|c|}{ Heterogeneity: $\mathrm{Tau}^{2}=0,07 ; \mathrm{Chi}^{2}=4,00, \mathrm{df}=2(P=0,14) ; I^{2}=50 \%$} & -1 \\
\hline
\end{tabular}

Test for subgroup differences: Not applicable

IX. táblázat

Plakk indexek összehasonlítása (2.1 eredmények)

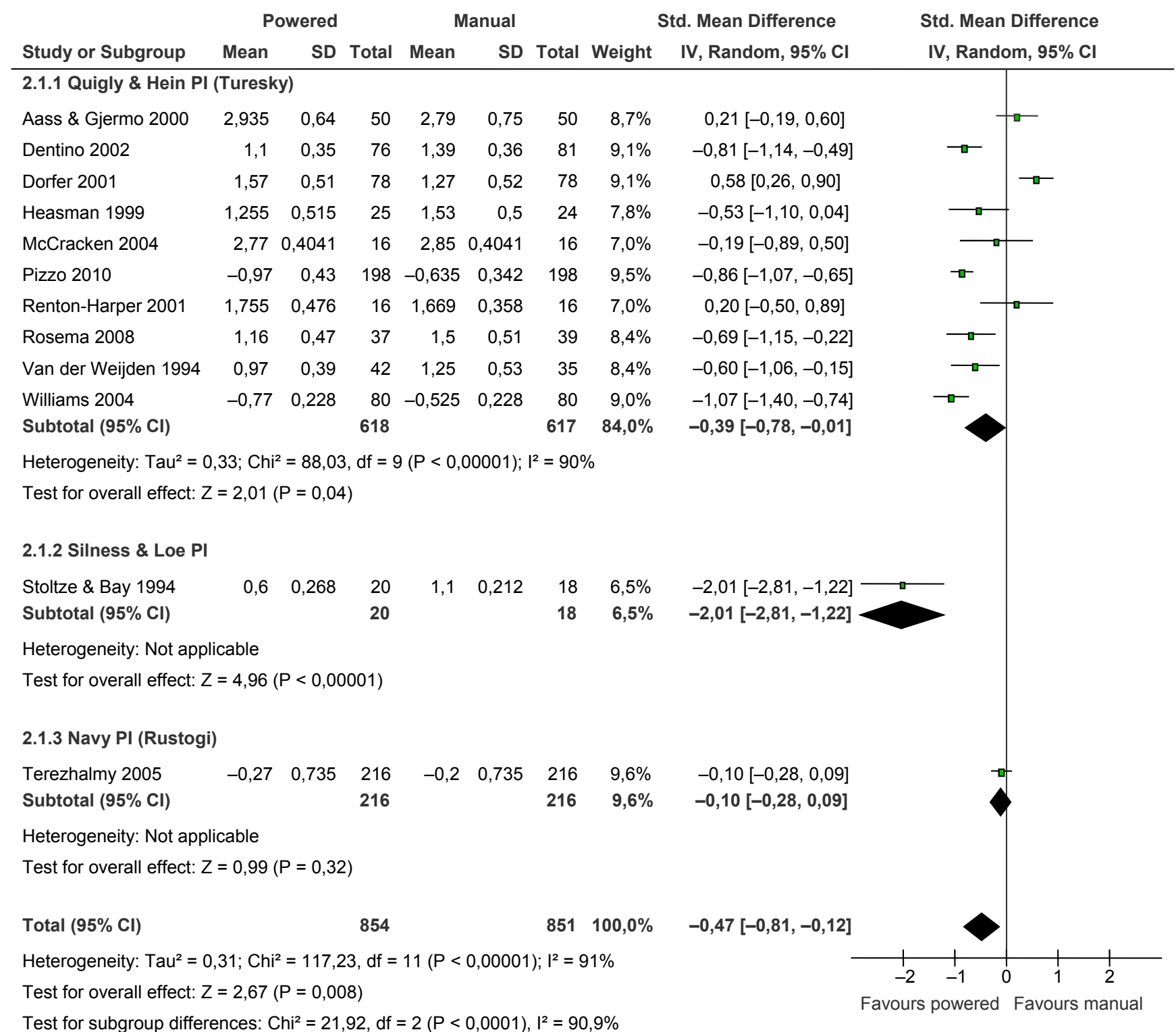


Gingivális indexek összehasonlítása (2.2 eredmények)

\begin{tabular}{|c|c|c|c|c|c|c|c|c|c|}
\hline \multirow[b]{2}{*}{ Study or Subgroup } & \multicolumn{3}{|c|}{ Powered } & \multicolumn{3}{|c|}{ Manual } & \multicolumn{2}{|r|}{ Std. Mean Difference } & \multirow{2}{*}{$\begin{array}{l}\text { Std. Mean Difference } \\
\text { IV, Random, } 95 \% \mathrm{CI}\end{array}$} \\
\hline & Mean & SD & Total & Mean & SD & Total & Weight & IV, Random, 95\% CI & \\
\hline \multicolumn{10}{|l|}{ 2.2.1 Loe \& Silness GI } \\
\hline Aass \& Gjermo 2000 & 1,215 & 0,135 & 50 & 1,19 & 0,11 & 50 & $13,8 \%$ & $0,20[-0,19,0,59]$ & \\
\hline Heasman 1999 & 1,55 & 0,21 & 25 & 1,64 & 0,22 & 24 & $12,4 \%$ & $-0,41[-0,98,0,15]$ & \\
\hline Stoltze \& Bay 1994 & 0,9 & 0,045 & 20 & 1,1 & 0,085 & 18 & $9,2 \%$ & $-2,93[-3,87,-1,98]$ & \\
\hline Subtotal $(95 \% \mathrm{Cl})$ & & & 95 & & & 92 & $35,4 \%$ & $-0,98[-2,44,0,48]$ & \\
\hline \multicolumn{10}{|c|}{ Heterogeneity: Tau $^{2}=1,54 ; \mathrm{Chi}^{2}=36,21, \mathrm{df}=2(\mathrm{P}<0,00001) ; \mathrm{I}^{2}=94 \%$} \\
\hline \multicolumn{10}{|c|}{ Test for overall effect: $Z=1,32(P=0,19)$} \\
\hline \multicolumn{10}{|l|}{ 2.2.2 Lobene mod. GI } \\
\hline Van der Weijden 1994 & 0,8 & 0,24 & 42 & 0,94 & 0,26 & 35 & $13,3 \%$ & $-0,56[-1,01,-0,10]$ & \\
\hline Subtotal $(95 \% \mathrm{Cl})$ & & & 42 & & & 35 & $13,3 \%$ & $-0,56[-1,01,-0,10]$ & \\
\hline \multicolumn{10}{|c|}{ Heterogeneity: Not applicable } \\
\hline \multicolumn{10}{|c|}{ Test for overall effect: $Z=2,38(P=0,02)$} \\
\hline \multicolumn{10}{|c|}{ 2.2.3 BOP (Ainamo \& Bay) } \\
\hline Dentino 2002 & 0,134 & 0,092 & 76 & 0,155 & 0,094 & 81 & $14,4 \%$ & $-0,22[-0,54,0,09]$ & \\
\hline Mantokoudis 2001 & 0,24 & 0,244 & 24 & 0,243 & 0,244 & 24 & $12,4 \%$ & $-0,01[-0,58,0,55]$ & \\
\hline Subtotal $(95 \% \mathrm{Cl})$ & & & 100 & & & 105 & $26,8 \%$ & $-0,17[-0,45,0,10]$ & \\
\hline \multicolumn{10}{|c|}{ Heterogeneity: $\mathrm{Tau}^{2}=0,00 ; \mathrm{Chi}^{2}=0,41, \mathrm{df}=1(\mathrm{P}=0,52) ; \mathrm{I}^{2}=0 \%$} \\
\hline \multicolumn{10}{|c|}{ Test for overall effect: $Z=1,25(P=0,21)$} \\
\hline \multicolumn{10}{|c|}{ 2.2.4 BOMP (van der Weijden) } \\
\hline Rosema 2008 & 0,57 & 0,36 & 37 & 0,61 & 0,285 & 39 & $13,4 \%$ & $-0,12[-0,57,0,33]$ & \\
\hline Subtotal $(95 \% \mathrm{Cl})$ & & & 37 & & & 39 & $13,4 \%$ & $-0,12[-0,57,0,33]$ & \\
\hline \multicolumn{10}{|c|}{ Heterogeneity: Not applicable } \\
\hline \multicolumn{10}{|c|}{ Test for overall effect: $Z=0,53(P=0,59)$} \\
\hline \multicolumn{10}{|c|}{ 2.2.5 Papillary BI (Mühlemann) } \\
\hline McCracken 2004 & 0,97 & 0,2742 & 16 & 0,77 & 0,2742 & 16 & $11,1 \%$ & $0,71[-0,01,1,43]$ & $\square$ \\
\hline Subtotal $(95 \% \mathrm{Cl})$ & & & 16 & & & 16 & $11,1 \%$ & $0,71[-0,01,1,43]$ & \\
\hline \multicolumn{10}{|c|}{ Heterogeneity: Not applicable } \\
\hline \multicolumn{10}{|c|}{ Test for overall effect: $Z=1,94(P=0,05)$} \\
\hline Total $(95 \% \mathrm{Cl})$ & & & 290 & & & 287 & $100,0 \%$ & $-0,34[-0,79,0,11]$ & \\
\hline Heterogeneity: $\operatorname{Tau}^{2}=$ & ,34; $\mathrm{Chi}^{2}$ & $2=45,74$ & $4, \mathrm{df}=7$ & $7(\mathrm{P}<0$, & ,00001); & $1^{2}=85^{c}$ & & & $\begin{array}{l}+ \\
-4\end{array}$ \\
\hline
\end{tabular}

Test for overall effect: $Z=1,47(P=0,14)$

Test for subgroup differences: $\mathrm{Chi}^{2}=9,74, \mathrm{df}=4(\mathrm{P}=0,04), \mathrm{I}^{2}=58,9 \%$ 
Szondázási mélység összehasonlítása (2.3 eredmények)

\begin{tabular}{|c|c|c|c|c|c|c|c|c|c|}
\hline \multirow[b]{2}{*}{ Study or Subgroup } & \multicolumn{3}{|c|}{ Powered } & \multicolumn{3}{|c|}{ Manual } & \multicolumn{2}{|c|}{ Std. Mean Difference } & \multirow{2}{*}{$\begin{array}{l}\text { Std. Mean Difference } \\
\text { IV, Random, } 95 \% \mathrm{CI}\end{array}$} \\
\hline & Mean & SD & Total & Mean & SD & Total & Weight & IV, Random, $95 \% \mathrm{CI}$ & \\
\hline \multicolumn{10}{|c|}{ 2.3.1 Pocket probing depth $(\mathrm{mm})$} \\
\hline Dentino 2002 & 1,75 & 0,34 & 76 & 1,68 & 0,4 & 81 & $83,4 \%$ & $0,19[-0,13,0,50]$ & \\
\hline McCracken 2004 & 3,07 & 0,3608 & 16 & 2,9 & 0,3608 & 16 & $16,6 \%$ & $0,46[-0,24,1,16]$ & \\
\hline Subtotal $(95 \% \mathrm{Cl})$ & & & 92 & & & 97 & $100,0 \%$ & $0,23[-0,05,0,52]$ & \\
\hline \multicolumn{10}{|c|}{ Heterogeneity: $\mathrm{Tau}^{2}=0,00 ; \mathrm{Chi}^{2}=0,48, \mathrm{df}=1(\mathrm{P}=0,49) ; \mathrm{I}^{2}=0 \%$} \\
\hline \multicolumn{10}{|c|}{ Test for overall effect: $Z=1,59(P=0,11)$} \\
\hline Total $(95 \% \mathrm{Cl})$ & & & 92 & & & 97 & $100,0 \%$ & $0,23[-0,05,0,52]$ & \\
\hline \multicolumn{9}{|c|}{ Heterogeneity: $\mathrm{Tau}^{2}=0,00 ; \mathrm{Chi}^{2}=0,48, \mathrm{df}=1(\mathrm{P}=0,49) ; \mathrm{I}^{2}=0 \%$} & $\vdash$ \\
\hline \multicolumn{9}{|c|}{ Test for overall effect: $Z=1,59(P=0,11)$} & Favours powered Favours $m$ \\
\hline
\end{tabular}

XII. táblázat

Plakk indexek összehasonlítása (3.1 eredmények)

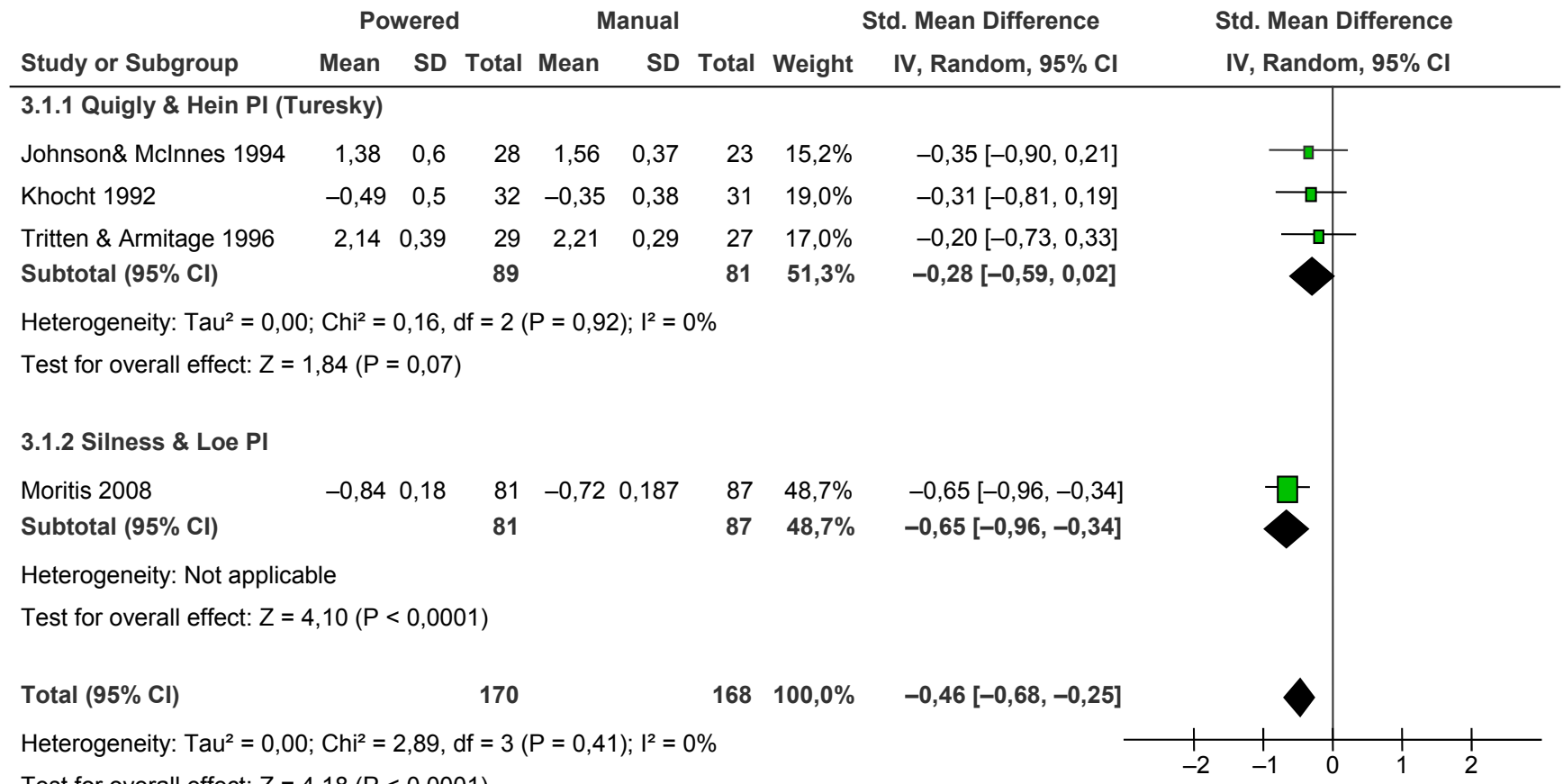

Test for overall effect: $Z=4,18(P<0,0001)$

Test for subgroup differences: $\mathrm{Chi}^{2}=2,73, \mathrm{df}=1(\mathrm{P}=0,10), \mathrm{I}^{2}=63,3 \%$
Favours powered Favours manual 
Gingivális indexek összehasonlítása (3.2 eredmények)

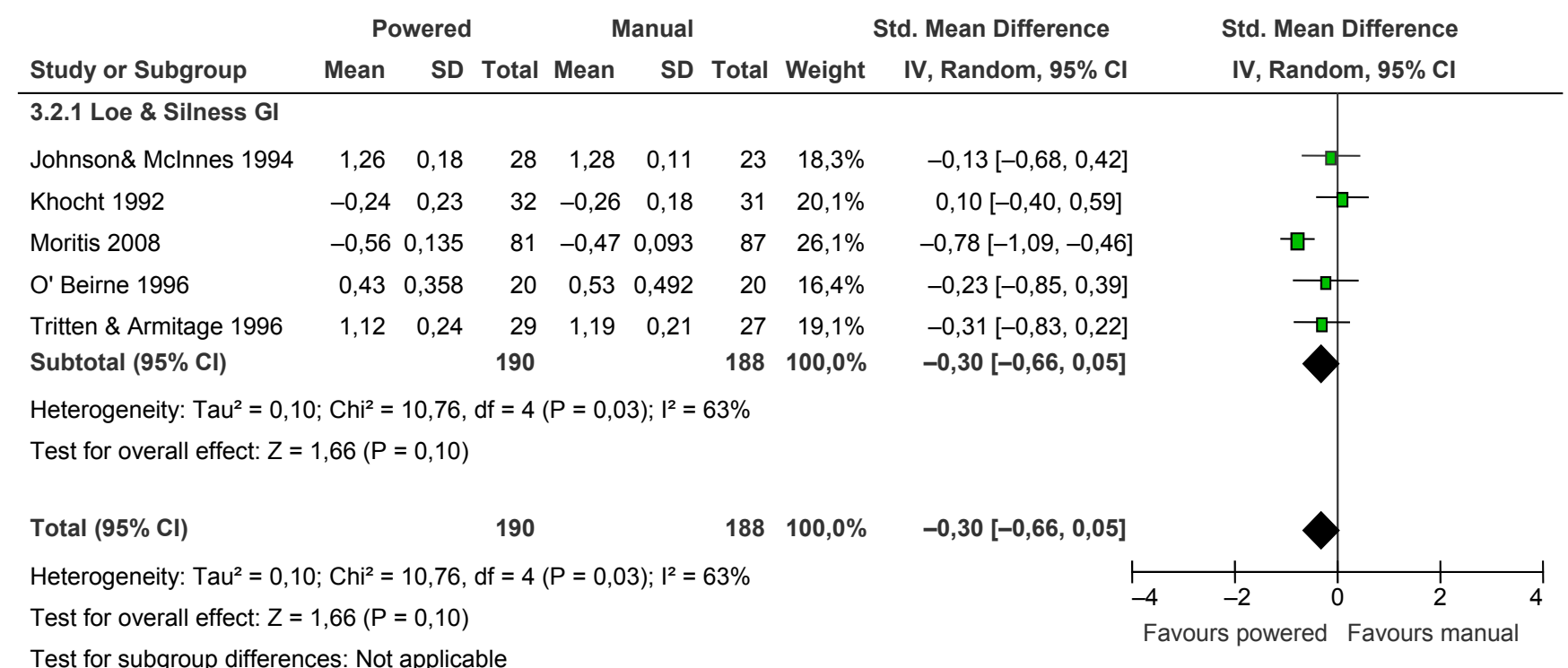

Test for subgroup differences: Not applicable

XIV. táblázat

Szondázási mélység összehasonlítása (3.3 eredmények)

\begin{tabular}{|c|c|c|c|c|c|c|c|c|c|c|c|}
\hline \multirow[b]{2}{*}{ Study or Subgroup } & \multicolumn{3}{|c|}{ Powered } & \multicolumn{3}{|c|}{ Manual } & \multicolumn{2}{|r|}{ Std. Mean Difference } & \multirow{2}{*}{\multicolumn{3}{|c|}{$\begin{array}{l}\text { Std. Mean Difference } \\
\text { IV, Random, } 95 \% \mathrm{CI}\end{array}$}} \\
\hline & Mean & SD & Total & Mean & SD & Total & Weight & IV, Random, $95 \% \mathrm{CI}$ & & & \\
\hline \multicolumn{12}{|c|}{ 3.3.1 Pocket probing depth } \\
\hline O' Beirne 1996 & 4,33 & 0,402 & 20 & 4,56 & 0,626 & 20 & $100,0 \%$ & $-0,43[-1,06,0,20]$ & & & \\
\hline Subtotal $(95 \% \mathrm{Cl})$ & & & 20 & & & 20 & $100,0 \%$ & $-0,43[-1,06,0,20]$ & & & \\
\hline \multicolumn{12}{|c|}{ Heterogeneity: Not applicable } \\
\hline \multicolumn{12}{|c|}{ Test for overall effect: $Z=1,34(P=0,18)$} \\
\hline Total $(95 \% \mathrm{Cl})$ & & & 20 & & & 20 & $100,0 \%$ & $-0,43[-1,06,0,20]$ & & & \\
\hline \multicolumn{9}{|c|}{ Heterogeneity: Not applicable } & & & \\
\hline \multicolumn{9}{|c|}{ Test for overall effect: $Z=1,34(P=0,18)$} & $\begin{array}{c}-2 \\
\text { Favours }\end{array}$ & $\begin{array}{c}-1 \\
\text { powered }\end{array}$ & anual \\
\hline
\end{tabular}

fogkefék között egyik vizsgált paraméter vonatkozásában sem.

\section{Heterogenitás vizsgálata}

A tanulmányok értékelése során nagyfokú heterogenitást találtunk, amely vonatkozott a plakk- és gingivális index értékekre mind az összes típusú és az oszcillálórotáló elektromos fogkefék csoportjában is. A legszembetűnőbb torzítást Stoltze \& Bay 1994 vizsgálata okozta, ahol kivételesen nagy volt a standardizált átlag különbsége, melyhez alacsony standard deviációk tartoztak. Ez erős szignifikáns előnyt mutat az elektromos fogkefék javára (IV-V., IX-X. táblázat).

\section{Szenzitivitási analízis}

A plakk indexet vizsgáló tesztnél egy kivételével a különböző minőségű vizsgálatok hasonló hatást becsültek, mint az összesített hatás, amely alátámasztja, hogy az eredmények erősek, és az alacsonyabb minőségű tanulmányok nem torzítják azt. Ez alól csak a nem szponzorált kutatások (8 közlemény) csoportja a kivétel, melyeket meta-analízis alá vetve már nincs szignifikáns különbség a két típusú fogkefe között ( $X V$. táblázat).

A gingivális indexek terén az alcsoportok nagyfokú szenzitivitást mutattak. A plakk indexszel ellentétben itt csak egy alcsoport (gyártó által nem szponzorált tanulmányok) becsült hasonló hatást, mint az összhatás. Az összes többi alcsoport nem mutatott szignifikáns kü- 
Szenzitivitási vizsgálat

\begin{tabular}{|c|c|c|c|c|c|c|c|}
\hline $\begin{array}{l}\text { Kiválasztott } \\
\text { csoport }\end{array}$ & Index & $\begin{array}{c}\text { Tanulmányok } \\
\text { száma }\end{array}$ & $\begin{array}{c}\text { SMD } \\
(95 \% \mathrm{Cl})\end{array}$ & $\begin{array}{c}\text { Hatás } \\
\text { P-értéke }\end{array}$ & $\begin{array}{l}\text { Het. } \\
\mathrm{Chi}^{2}\end{array}$ & $\begin{array}{c}\text { Het. } \\
\text { P-értéke }\end{array}$ & $\begin{array}{c}1^{2} \\
(\%)\end{array}$ \\
\hline Minden tanulmány & plakk & 19 & $-0,40(-0,65,-0,15)$ & 0,002 & 132,23 & $<0,001$ & $86 \%$ \\
\hline „Teljes-száj” mérések & plakk & 16 & $-0,38(-0,66,-0,10)$ & 0,009 & 129,63 & $<0,001$ & $88 \%$ \\
\hline Megfelelő randomizáció & plakk & 6 & $-0,48(-0,90,-0,06)$ & 0,03 & 29,90 & $<0,001$ & $83 \%$ \\
\hline Megfelelő maszkolás & plakk & 18 & $-0,41(-0,67,-0,15)$ & 0,002 & 131,83 & $<0,001$ & $87 \%$ \\
\hline Gyártó által nem szponzorált & plakk & 8 & $-0,35(-0,90, \quad 0,19)$ & 0,20 & 85,02 & $<0,001$ & $92 \%$ \\
\hline Homogén csoportok & plakk & 8 & $-0,31(-0,53,-0,08)$ & 0,009 & 10,88 & 0,14 & $36 \%$ \\
\hline Követéses vizsgálatok & plakk & 13 & $-0,50(-0,74,-0,26)$ & $<0,001$ & 36,10 & $<0,001$ & $67 \%$ \\
\hline $\begin{array}{l}\text { Kiválasztott } \\
\text { csoport }\end{array}$ & Index & $\begin{array}{c}\text { Tanulmányok } \\
\text { száma }\end{array}$ & $\begin{array}{c}\text { SMD } \\
(95 \% \mathrm{Cl})\end{array}$ & $\begin{array}{c}\text { Hatás } \\
\text { P-értéke }\end{array}$ & $\begin{array}{l}\text { Het. } \\
\text { Chi }^{2}\end{array}$ & $\begin{array}{c}\text { Het. } \\
\text { P-értéke }\end{array}$ & $\begin{array}{c}1^{2} \\
(\%)\end{array}$ \\
\hline Minden tanulmány & gingivális & 16 & $-0,29(-0,55,-0,02)$ & 0,04 & 69,55 & $<0,001$ & $78 \%$ \\
\hline „Teljes-száj” mérések & gingivális & 11 & $-0,25(-0,62, \quad 0,12)$ & 0,19 & 63,22 & $<0,001$ & $84 \%$ \\
\hline Megfelelő randomizáció & gingivális & 5 & $-0,01(-0,30, \quad 0,28)$ & 0,94 & 8,08 & 0,09 & $51 \%$ \\
\hline Megfelelő maszkolás & gingivális & 15 & $-0,25(-0,52, \quad 0,02)$ & 0,07 & 65,56 & $<0,001$ & $79 \%$ \\
\hline Gyártó által nem szponzorált & gingivális & 6 & $-0,69(-1,33,-0,05)$ & 0,03 & 36,75 & $<0,001$ & $86 \%$ \\
\hline Homogén csoportok & gingivális & 10 & $-0,08(-0,30, \quad 0,15)$ & 0,51 & 16,50 & 0,06 & $45 \%$ \\
\hline Követéses vizsgálat & gingivális & 14 & $-0,35(-0,64,-0,05)$ & 0,02 & 62,36 & $<0,001$ & $79 \%$ \\
\hline
\end{tabular}

lönbséget a két eszköz között, ami az összhatás gyenge voltát mutatja. Ez az alacsonyabb minőségi kritériumokkal illetett vizsgálatok torzító hatásának tudható be.

A követéses vizsgálatokat külön értékelve, a plakkés gingivális indexeknél ugyanazt az eredményt kaptuk, mint az összhatásnál. Az analízisben tehát a nagyobb mintahányaddal képviselő cross-over vizsgálatok nem torzítják el a végeredményt.

\section{Káros hatások - szöveti trauma}

Három tanulmány közölt statisztikailag feldolgozható adatot a fogkefék biztonságosságára nézve [Dentino 2002, Mantokoudis 2001, Rosema 2008]. Egy az ínyrecesszió változását, míg másik kettő a GAS (gingival abrasion score) [Danser 1998] értéket regisztrálta. A meta-analízis nem mutatott szignifikáns különbséget a két eszköz között (VII. táblázat). A beválogatott publikációk közül nyolc nem szolgált leírással e tekintetben. További 16 tanulmány közölt megfigyeléseik alapján leíró jellegű adatot. Ebből 11 nem talált egyáltalán szöveti traumát [Aass\& Gjermo 2000, Ainamo 1997, Erbe 2013, Johnson\& Mclnnes 1994, Moritis 2008, Pizzo 2010, Quirynen 1994, Stoltze \& Bay 1994, Terézhalmy 2005, van der Weijden 2002, Williams 2004], míg 5 közölt leírást traumatizáló hatásra. Ez utóbbi ötöt tovább boncolgatva három esetben [O’Bierne 1996, van der Weijden 1994, Terézhalmy 1995] nem volt a két eszköz között szignifikáns különbség, vagy a lágyszöveti trauma elhanyagolható volt. Egy kutatás közölt négy felszíni gingivális abráziót a kézi és egyet az elektromos fogkefe esetében [Tritten \& Armitage 1996], míg egy másik hét lágyszöveti változást észlelt az elektromos és négyet a kézi fogkefe esetében [Khocht 1992].

\section{Megbeszélés}

A mindennapi otthoni fogmosás legfontosabb szerepe a parodontális és cariológiai, illetve azok következményes megbetegedéseinek megelőzése. Mind a mai napig a mechanikus plakk-kontroll a legelfogadottabb és leghatásosabb módja a prevenciónak [Axelsson 1976, 2004]. A hatékonyság és megbízhatóság érdekében a gyártók rengeteg új szájhigiéniás eszközt hoztak forgalomba, illetve az elektromos fogkefék fejlesztése felgyorsult és reklámozása felerősödött. A választást a termékek közül nemcsak a személyes preferenciák, elérhetőség, megfizethetőség, hanem a szakmabeliek javaslatai is nagyban befolyásolják. A fogorvosoknak is nagy szerepe van tehát abban, hogy a több szintǔ szájüregi prevenció során a leghatékonyabb eszközöket tudjuk ajánlani a pácienseknek.

Meta-analízisünk eredményei azt mutatják, hogy az elektromos fogkefék típustól függetlenül körülbelül $9 \%$-al jobban távolítják el a plakkot és 6\%-al jobban csökkentik az ínygyulladást, mint a kézi társaik. Eredményeink korrelálnak a Cochrane Adatbázis meta-analízisével, ahol a gépi fogkefék $11 \%$-al hatékonyabban távolítják el a lepedéket és $9 \%$-al jobban csökkentik az ínygyulladást 1-3 hónapos megfigyelési idő alatt [Robinson 2005].

Működési elv szerint tovább vizsgálva a hatékonyságot, az oszcilláló-rotáló (pulzáló), a szónikus laterális és ultraszónikus rezgőmozgást végző elektromos fogkefék 
szignifikánsan nagyobb plakk index csökkenést eredményeztek, mint a kézi fogkefével végzett fogmosás. A gingivális indexeknél az eredmények már nem voltak ilyen egyértelműek. Az ellen-oszcilláló elektromos fogkefe kivételével az összes többi csoportnál nem volt szignifikáns eltérés a két típusú eszköz között.

A meta-analízis eredményét némiképp árnyalja, hogy sok faktor befolyásolja a fogkefe hatékonyságát, beleértve az elemi szálak méretét, orientációját, elrendezését, keménységét, alakját, a kefefej méretét, alakját, illetve az időmérő jelenétét vagy hiányát. Ezt a sok apró tényezőt nem lehetséges külön-külön csoportosítani és analizálni. Az azonban elfogadottnak tünik, hogy a fogmosás során alkalmazott nyomás és a plakkeltávolítás hatásfoka között gyenge a korreláció [Van der Weijden 1996, Danser 1998b]. A kézi módszer során az összefüggés nem lineáris, egy bizonyos határ fölött nemhogy nem nő, hanem csökken a hatékonyság, viszont az erő növelésével egy darabig eredményesebben lehet a plakkot eltávolítani [Van der Weijden 1998]. Gépi eszközök összehasonlítása során a szerző szintén arra a következtetésre jutott, hogy a nagy erő alkalmazása rontja a hatékonyságot [Van der Weijden 2004].

Brit iskolások körében végzett tanulmány szerint a fogmosásra fordított átlagos idő 1 perc [MacGregor 1979]. Azonban szoros az összefüggés a fogmosásra fordított idő és az eltávolított lepedék között. Az idő növelése egy ideig arányosan növeli a hatékonyságot, és kb. 30 másodperc/quadráns után már alig emelkedik elektromos fogkefe esetén (93\%-os hatékonyság), míg kézi társainál akár 6 percig is nő a hatékonyság (84\%-ig). A kézi és gépi eszközök időráfordítás-hatékonyság-mutatói közti különbség az utóbbi javára billenti a mérleget [Claydon 2008]. Az adatok szerint a teljes szájra fordított ajánlott minimumidő a 2 perc [Van der Weijden 1993, Williams 2004].

Figyelemreméltó információkhoz juthatunk ugyanakkor a hosszú távú követéses publikációk részletes vizsgálatakor. Két tanulmány számol be egyéves vagy annál hosszabb követési vizsgálatok eredményeiről [Ainamo 1997, McCracken 2004], és egyik sem talált szignifikáns különbséget az eszközök között plakkeltávolító hatásukat illetően. Érdemes szemügyre venni azt a körülményt is, amikor a résztvevők nem laikusok, hanem szakemberek. Néhány vizsgálat ugyanis fogorvostanhallgatókon végezte méréseit [Ainamo 1991, Mantokoudis 2001, van der Weijden 1991], és szintén nem talált prioritást egyik eszköz javára sem.

Választ kerestünk arra is, hogy vajon a helyes edukáció, a páciens instruálása és motiválása milyen mértékben befolyásolja vagy árnyalja az elektromos fogkefék hatékonyságát. Több vizsgálatban a jelentkezők professzionális szájhigiénés edukációban részesültek, ahol már szintén nem mutatkozott meg az elektromos fogkefe hatékonyabb volta [Haffajee 2001, Terezhalmy 1995, Tritten \& Armitage 1996]. Úgy tűnik tehát, hogy a professzionális egyéni szájhigiénés képzésben részt vett, motivált páciensek egyenértékű hatást tudnak el- érni a kézi fogkefével is [Haffejee 2001]. Az elektromos fogkefék leginkább az instruálásban nem részesült (maximum a gyártók írásbeli instrukciói álltak rendelkezésre) csoportokban mutattak szignifikánsan jobb eredményeket [Dentino 2002, Stoltze \& Bay 1994].

Régóta tudjuk, hogy a legjobb szájhigiéniát a megfelelő otthoni individuális plakk-kontroll biztosítja, mely kiegészül a rendszeres professzionális szájhigiénés kezeléssel és a folyamatos (legalább 6 havonta) ellenőrzéssel egybekötött instruációval [Ash 1964, Forgas-Brockmann 1998]. Sajnos ez az ideális állapot az átlag populáció nagy részének nem adatik meg [Ainamo 1997]. Jó lett volna a tanulmányokból következtetést levonni, hogy 6, illetve 12 hónapos távlatban a csökkenő motiváció mennyiben befolyásolja a tisztítás hatékonyságának különbözőségét a két eszköz esetében. Annak ugyanis klinikai következménye lehet, ha újramotiválás nélkül jelentős különbség észlelhető a plakkeltávolítás hatékonyságában, ismerve a fenntartó terápia és a motiváció jelentőségét, és hiányának következményeit mind a caries, mind a fogágy elváltozások kapcsán. Habár a megfelelő instruációval úgy tűnik, elkerülhetjük a költséges elektromos fogkefe használatát, ugyanakkor bizonyos esetekben, például rosszabb kézügyesség, szellemi vagy testi fogyatékosság, kórházi kezelés esetén nagy segítség az elektromos eszköz használata.

Az irodalom megfelelő bizonyítékkal szolgál arra, hogy a helyes fogmosás megszünteti az ínygyulladást [Lang 1973], megelőzheti a fogágypusztulást, és fluorid tartalmú fogkrémet használva redukálja a caries incidenciáját. Ezek az előnyök mind kézi, mind elektromos fogkefe használata esetén fennállnak, és a meta-analízisnek nem célja sugallni, hogy a fogmosás csak az utóbbi esetén lehet kielégítő. Továbbá fennáll a kérdés, hogy milyen szintű plakk- és gingiválisindex-csökkenés vezet klinikailag is szignifikánsan megmutatkozó parodontális állapot javuláshoz. Egyes szaktekintélyek önkéntes küszöbértékek felállítást javasolták bizonyos eszközök felsőbbrendűségének megállapításához. Példának okáért Imrey és mtsai szerint egy eszköz hatása csak akkor lehet klinikailag előnyösebb egy másikénál, ha legalább 20\%-os különbséget mutat teljesítményben [Imrey 1992, 1994]. Ezt a küszöbértéket egyik típusú elektromos fogkefe sem produkálta meta-analízisünkben. Más szerző szerint 0,18-0,32 plakk index differenciáról, mely statisztikailag ugyan szignifikáns lehet, klinikai hatáskülönbségében nem feltétlen mondható el, hogy az egyik eszköz prioritást élvezne a másik felett [Listgarten 1992].

A helyzet tovább nehezedik parodontitisben szenvedő egyének esetén, hisz a betegség kialakulásához a plakk jelenlétén kívül egyéb faktorok is befolyásoló szereppel bírnak, úgymint a dohányzás, genetika és szisztémás betegségek stb. A parodontitis kialakulásához általában több év szükségeltetik és a tanulmányok nem rendelkeznek ekkora követési idővel. Sőt, a plakk és a gingivitis nem megbízható kórjelzője az agresszív fogágybetegségnek, ezért ezen okokból kifolyólag nehéz megbecsülni a klinikai küszöbértékét a szignifikáns 
plakk-redukciónak a betegség megelőzését és gyógyítását illetően. Következésképpen az oszcilláló-rotáló és egyéb elektromos fogkefék nagyobb plakkeltávolító hatásának klinikai relevanciája és következménye nehezen megállapítható. Egyértelmú azonban, hogy a már kialakult parodontális tapadásveszteség csökkentéséhez, illetve megállításához a rendszeres professzionális szájhigiéniás kezelés elengedhetetlen [Axelsson \& Lindhe 1981, 1991, 2004].

A prevenciós hatás szemszögéből továbbá nem szabad elfeledkezni az interdentális területekről sem. A témában közölt tanulmányok hiányossága, hogy hiába mér egy fog 6 felszínén (3 bukkális, 3 orális), az approximalis felszínek kontakt pont körüli centrális területe nem kerül regisztrálásra. Pedig éppen ezen felszínek a legfontosabb predilekciós helyei a sima felszíni cariesnek, gingivitisnek és a parodontitisnek. Ez tovább nehezíti a vizsgált eszközök klinikai hatásának megítélését, hiszen önmagában, fogköz-tisztítás nélkül sem a manuális, sem az elektromos fogkefe nem elégséges a szájüregi prevencióban [Gjermo 1970, Warren 1996].

A fogmosás által okozott traumatizáló hatást már régen leírták [Joshipura 1994, Sangnes 1976]. Az elektromos fogkefék okozta káros kemény- és lágyszöveti mellékhatásokra vonatkozó adatok minimálisak. A rövid távú randomizált kontrollált vizsgálatok talán nem is a legjobban megfelelők ezen káros hatások felderítésére [Robinson 2005]. Az ínyen okozott sérüléseket a szerzők kicsinynek és tranziensnek minősítették. Ráadásul a hosszútávú (> 1 év) követéses, illetve parodontitises (feltehetően ínyrecesszióval rendelkező) alanyokat vizsgáló közlemények száma még kevesebb. Egy tanulmány parodontitisben szenvedő önkénteseket vizsgált 8 hónapig, és nem talált lágyszöveti káros mellékhatást egyik eszköz használata során sem [Quirynen 1994]. Egyik másik szerző [Ainamo 1997] is hasonló eredményt tapasztalt az átlag felnőtt lakosság körében egyéves követése alatt. Egy évnél hosszabb követéssel (16 hónap) csak egy közlemény publikált krónikus parodontitises páciensek körében eredményeket [McCracken 2004], azonban a káros mellékhatásokat nem vizsgálták. Továbbá nehezen megítélhető a lágyszöveti traumán kívül az elektromos fogkefék évekig történő használata során keletkező fognyaki abrázió mértéke is. Szakértői csoportok ajánlása szerint az elektromos fogkefék biztonságosak, ha megfelelően használjuk őket, bár ennek megítélése további vizsgálatokat igényel [Lang 1998].

A gyártók által szponzorált vizsgálatokban elméletileg feltételezhető bizonyos részrehajlás jelenléte, hiszen a gyártó szeretne tudományos bizonyítékot kapni elektromos fogkeféje hatékonyságáról és megbízhatóságáról. A gyógyszer- és gyógyászati segédeszközgyártó cégek által szponzorált vizsgálatok nagyobb valószínúséggel favorizálják a teszt-terméket [Lexchin 2003]. Systematic review-nk esetében is feltételezhető ez az állítás, mert a minőségi paraméterek vizsgálata során részrehajlás szempontjából két publikációt magas és az összes többit közepes rizikójúnak találtuk. A szenzitivitási analízis is alátámasztani látszik kijelentésünket. Plakk mennyiségének vizsgálatakor a gyártók által nem szponzorált tanulmányokban már nem jött ki a szignifikáns különbség az elektromos fogkefe javára. Gingivális index terén úgy tünik, a szponzoráltság nem befolyásolja a végeredményt, de az összes többi minőségi szempont szerint elemezve a becsült hatás nem egyezik az összhatással. Gingivális index tekintetében tehát úgy tünik, hogy az összhatás, ami szerint az elektromos fogkefék jobban csökkentik az ínygyulladást, gyenge evidenciájú, mely az alacsonyabb minőségi kritériumú publikációk torzításának köszönhető.

Általánosságban a tanulmányok megfeleltek ugyan a legfontosabb minőségi kritériumoknak, de egy esetben sem találkoztunk olyannal, ami minden szempont szerint részrehajlásmentes lett volna.

\section{Következtetések}

Analízisünk eredményei alapján elmondható, hogy az elektromos eszközök legalább olyan hatásosak, mint a kézi fogkefék, és a lágyszövetekre nézve biztonságosan használhatók. A keményszövetekre gyakorolt lehetséges káros mellékhatás megítélésére csekély a rendelkezésre álló információ.

Általánosságban az elektromos fogkefék hatékonyabban távolítják el a plakkot és jobban csökkentik a gingivitist, mint kézi társaik. Legjobb eredménnyel az oszcilláló-rotáló (pulzáló) fogkefék szolgáltak. A gingivitis csökkentésében azonban szignifikáns különbséget nem mutatattak ki. A klinikai relevanciája ezeknek a statisztikailag szignifikáns redukcióknak ugyanakkor nem ismeretes. A rendelkezésre álló vizsgálatok mennyisége és követési ideje túl kevés ahhoz, hogy mélyreható következtetést vonhatnánk le az elörehaladott fogágypusztulásra gyakorolt hatásukról.

Eredményeink megerősítik az egyénre szabott tanácsadás és motiválás jelentőségét.

Kevés az olyan tanulmány, aminek követési ideje meghaladja a fél évet. Az elektromos fogkefék teljes hatékonyságának megállapításához több hosszútávú követéses RCT vizsgálatra lenne szükségünk.

Számos közleményben találni közepes, vagy súlyos minőségi, metodikai hiányosságokat. A jövőbeni jobb összehasonlíthatóság végett ajánlatos a kutatóknak a tervezésben és publikálásban a CONSORT irányelveket követni, valamint az indexeket standardizálni.

\section{Köszönetnyílvánítás}

Szeretnénk köszönetet mondani Dr. Deutsch Tibornak, a Semmelweis Egyetem Egészségtudományi Kar tanárának a statisztikai adatfeldolgozás során nyújtott nélkülözhetetlen segítségéért, illetve Dr. Kuhajda Péternek, aki az absztraktok szürésében vett részt. 


\section{Irodalom}

1. Aass AM, GJermo P: Comparison of oral hygiene efficacy of one manual and two electric toothbrushes. Acta Odontol Scand 2000. Aug; 58(4): 166-170.

2. Addy M, Dummer PM, Griffiths G, Hicks R, Kingdom A, Shaw WC: Prevalence of plaque, gingivitis and caries in 11-12-year-old children in South Wales. Community Dent Oral Epidemiol 1986; 14(2): 115-118.

3. AINAMO J, BAY I: Problems and proposals for recording gingivitis and plaque. Int Dent J 1975; 25(4): 229-235.

4. Ainamo J, Hormia M, Kaunisaho K, Sorsa T, Suomaiainen K: Effect of manual versus powered toothbrushes. J Dent Res 1991; $70,557$.

5. Ainamo, J, Xie Q, Ainamo A, Kallo P: Assessment of the effect of an oscillating/ rotating electric toothbrush on oral health. A 12 month longitudinal study. J Clin Periodontol 1997; 24, 28-33.

6. Axelsson P, Lindhe J, Nystrom B: On the prevention of caries and periodontal disease. Results of a 15 year longitudinal study in adults. J Clin Periodontol 1991; 18: 182-189.

7. AXELSSON P, LINDHE J, WÄSEBY J: The effect of various plaque control measures on gingivitis and caries in schoolchildren. Community Dent Oral Epidemiol: 1976 Nov; 4(6): 232-239.

8. AxELSSON P, LINDHE J: Effect of controlled oral hygiene procedures on caries and periodontal disease in adults. Results after 6 years. J Clin Periodontol 1981; a: 8: 239-248.

9. AxELSSON P, LINDHE J: The significance of maintenance care in the treatment of periodontal disease. J Clin Periodontol 1981; b: 8: 281-294.

10. Axelsson $P$, Nystrom $B$, Lindhe J: The long-term effect of a plaque control program on tooth mortality, caries and periodontal disease in adults. Results after 30 years of maintenance. $J$ Clin Periodontol 2004; 34: 749-757.

11. Barnes, C. M., Weatherford, T. W. III, Menaker L: A comparison of the Braun Oral-B Plaque Remover (D5) electric and a manual toothbrush in affecting gingivitis. J Clin Dent 1993; 4, 48-51.

12. Borenstein M, Hedges LV, Higgins JPT, Rothstein HR: Introduction to Meta-Analysis @ 2009, John Wiley \& Sons, Ltd.

13. Chesters RK, Huntington E, Burchell CK, Stephen KW: Effects of oral care habits on caries in adolescents. Caries Res 1992; 26(4): 299-304.

14. CLAYDon NC: Current concepts in toothbrushing and interdental cleaning. Periodontol 2000 2008; 48: 10-22.

15. Cronin M, Dembling W, Warren PR, King DW: A 3-month clinical investigation comparing the safety and efficacy of a novel electric toothbrush (Braun Oral-B 3D Plaque Remover) with a manual toothbrush. Am J Dent 1998; 11, 17-21.

16. Cronin MJ, Dembling W, Conforti NJ, Liebman J, Cugini M, WarREN PR: A single-use and 3-month clinical investigation of the comparative efficacy of a battery-operated power toothbrush and a manual toothbrush. Am J Dent 2001; 14: 19B-24B.

17. D'Agostino RB. Discussion: Logical and analytic issues in dental/ oral product comparison research. J Periodontal Res 1992; 27(4 Pt 2): 349-351.

18. Danser MM, Timmerman MF, IJzerman $Y$, Van der Velden U, WarREN PR, VAN DER WEIJDEN FA: A comparison of electric toothbrushes in their potential to cause gingival abrasion of oral soft tissue. Am J Dent 1998; 11:35-39.

19. Danser MM, Timmerman MF, Jzerman Y, Piscaer Mi, van der VelDEN U, VAN DER WEIJDEN GA: Plaque removal with a novel manual toothbrush (X-Active) and the Braun Oral-B 3D Plaque Remover. $J$ Clin Periodontol 2003. Feb; 30(2): 138-144.

20. Danser MM, Timmerman MF, IJzerman $Y$, Bulthuis $\mathrm{H}$, Van der VelDEN U, VAN DER WeIJDEN GA: Evaluation of the incidence of gingival abrasion as a result of toothbrushing. J Clin Periodontol 1998; 25, 701-706

21. Day J, Martin MD, Chin M: Efficacy of a sonic toothbrush for plaque removal by care givers in a special needs population. Spec Care Dentist 1998; 18, 202-206.
22. Deeks JJ, Altman DG, Bradburn MJ: Statistical methods for examining heterogeneity and combining results from several studies in meta-analysis. In: EgGer M, Davey Smith G, Altman DG editors. Systematic reviews in health care. 2nd Edition. London: BMJ Books, 2001; 285-312.

23. Dentino aR, Derderian G, Wolf M, Cugini M, Johnson R, Van Swol RL, King D, Marks P, Warren P: Six-month comparison of powered versus manual toothbrushing for safety and efficacy in the absence of professional instruction in mechanical plaque control. J Periodontol 2002. Jul; 73(7): 770-778.

24. Dimosthenis M, Joss A, Christensen MM, Meng HX, Suvan JE, LANG NP: Comparison of the clinical effects and gingival abrasion aspects of manual and electric toothbrushes. J Clin Periodontol 2001; 28: 65-72.

25. Dörfer CE, von Bethlenfalvy ER, Staehle HJ, Pioch T: Comparison of the safety and efficacy of an oscillating/rotating battery-powered toothbrush and a standard manual toothbrush. Am J Dent 2001. Nov; 14 Spec No: 25B-28B.

26. Elbourne DR, Altman DG, Higgins JP, Curtin F, Worthington HV, VAlL A: Meta-analyses involving cross-over trials: methodological issues. Int J Epidemiol 2002; 31(1): 140-149.

27. ELLIOTT JR: A comparison of the effectiveness of a standard and electric toothbrush. J Clin Periodontol 1963; 34: 375-379.

28. Erbe C, Klukowska M, Tsaknaki I, Timm H, Grender J, Wehrbein H: Efficacy of 3 toothbrush treatments on plaque removal in orthodontic patients assessed with digital plaque imaging: a randomized controlled trial. Am J Orthod Dentofacial Orthop 2013. Jun; 143(6): 760-766.

29. Forgas-Brockmann LB, Carter-Hanson C, Killoy WJ: The effects of an ultrasonic toothbrush on plaque accumulation and gingival inflammation. J Clin Periodontol 1998. May; 25(5): 375-379.

30. Gjermo P, Fløtra L: The effect of different methods of interdental cleaning. J Periodont Res 1970; 5: 230-236.

31. Haffajee AD, Thompson M, Torresyap G, Guerrero D, SocranSKY SS: Efficacy of manual and powered toothbrushes (I). Effect on clinical parameters. J Clin Periodontol 2001. Oct; 28(10): 937946.

32. Heanue M, Deacon Sa, Deery C, Robinson PG, Walmsley ad, WORTHINGTON HV, SHAW WC: Manual versus powered toothbrushing for oral health. Cochrane Database of Systematic Reviews 2003, Issue 1

33. Heasman PA, Stacey F, Heasman L, Sellers P, Macgregor ID, KelLY PJ: A comparative study of the Philips HP 735, Braun/Oral B D7 and the Oral B 35 Advantage toothbrushes. J Clin Periodontol 1999. Feb; 26(2): 85-90.

34. Higgins JPT, Green S (editors). The Cochrane Handbook for Systematic Reviews of Interventions version 5.0.2 (updated September 2009). The Cochrane Collaboration 2009. Available from www.cochrane-handbook.org.

35. Ho PH, Niederman R: The effectiveness of the Sonicare sonic toothbrush on reduction of plaque, gingivitis, probing pocket depth and subgingival bacteria in adolescent orthodontic patients. J Clin Dent 1997; 8, 15-19.

36. Imrey PB, Chilton NW, Pihlstrom BL, Proskin hM, Kingman A, ListgaRten MA, et al.: Recommended revisions to American Dental Association guidelines for acceptance of chemotherapeutic products for gingivitis control. J Periodontal Res 1994; 29(4): 299-304.

37. IMREY PB: Logical and analytic issues in dental/oral product comparison research. J Periodontal Res 1992; 27(4 Pt 2): 328-341.

38. Johnson BD, Mclnnes C: Clinical evaluation of the efficacy and safety of a new sonic toothbrush. J Periodontol 1994; 65, 692697.

39. Joshipura KJ, Kent RL, DePaola PF: Gingival recession: intraoral distribution and associated factors. J Periodontol 1994. Sep; 65(9): 864-871.

40. Khocht A, Spindel L, Person P: A comparative clinical study of the safety and efficacy of three toothbrushes. $J$ Periodontol 1992. Jul; 63(7): 603-610. 
41. Kornman KS: Mapping the pathogenesis of periodontitis: a new look. J Periodontol 2008. Aug; 79(8 Suppl): 1560-1568.

42. Lang NP, Attstrom R, Löe H: Commonly used indices to assess oral hygiene and gingival and periodontal health and diseases. Proceedings of the European workshop on mechanical plaque control. Chicago: Quintessence, 1998; 50-71.

43. Lang NP, Cumming BR, LöE H: Toothbrushing frequency as it relates to plaque development and gingival health. $J$ Periodontol 1973; 44(7): 396-405.

44. Lexchin J, Bero LA, DJulbegovic B, Clark O: Pharmaceutical industry sponsorship and research outcome and quality: systematic review. BMJ 2003; 326(7400): 1167-1170.

45. LISTGARTEN MA: General issues in efficacy, equivalency, and superiority of trials: Clinical considerations. J Periodontal Res 1992; 27, 314-319.

46. LÖE H, SILNESS J: Periodontal disease in pregnancy. I. Prevalence and severity. Acta Odontol Scand 1963; 21: 533-551.

47. LÖE H, TheILAde E, Jensen SB: Experimental gingivitis in man $J$ Periodontol 1965; 36: 177-187.

48. MACGREGOR ID, RugG-GunN AJ: Survey of toothbrushing duration in 85 uninstructed English schoolchildren. Community Dent Oral Epidemiol. 1979; 7(5): 297-298.

49. Mantokoudis D, Joss A, Christensen MM, Meng HX, Suvan JE, LANG NP: Comparison of the clinical effects and gingival abrasion aspects of manual and electric toothbrushes. J Clin Periodontol 2001. Jan; 28(1): 65-72.

50. McCracken Gi, Heasman L, Stacey F, Steen N, DeJager M, Heasman PA: A clinical comparison of an oscillating/rotating powered toothbrush and a manual toothbrush in patients with chronic periodontitis. J Clin Periodontol 2004. Sep; 31(9): 805812.

51. Merchant A, Pitiphat W, Douglass CW, Crohin C, Joshipura K: Oral hygiene practices and periodontitis in health care professionals. J Periodontol 2002. May; 73(5): 531-535.

52. Moritis K, Jenkins W, Hefti A, Schmitt P, McGrady M: A randomized, parallel design study to evaluate the effects of a Sonicare and a manual toothbrush on plaque and gingivitis. J Clin Dent 2008; 19(2): 64-68.

53. Needleman IG: A guide to systematic reviews. $J$ Clin Periodontol 2002; 29 Suppl 3: 6-9; discussion 37-38. Review.

54. O'Beirne G, Johnson RH, Persson GR, Spektor MD: Efficacy of a sonic toothbrush on inflammation and probing depth in adult periodontitis. J Periodontol 1996. Sep; 67(9): 900-908.

55. Page RC, Kornman KS: The pathogenesis of human periodontitis: an introduction. Periodontol 2000 1997; 14: 9-11.

56. Pizzo G, Licata ME, Pizzo I, D’Angelo M: Plaque removal efficacy of power and manual toothbrushes: a comparative study. Clin Oral Investig 2010. Aug; 14(4): 375-381.

57. Quirynen M, Vervliet E, Teerlinck J, Darius P, van Steenberghe D: Medium- and long-term effectiveness of a counterrotational electric toothbrush on plaque removal, gingival bleeding, and probing pocket depth. Int J Periodontics Restorative Dent 1994. Aug; 14(4): 364-377.

58. Rapley JW, Killoy WJ: Subgingival and interproximal plaque removal using a counter-rotational electric toothbrush and a manual brush. Quintessence International 1994; 25, 39-42.

59. Renton-Harper P, Addy M, Newcombe RG: Plaque removal with the uninstructed use of electric toothbrushes: comparison with a manual brush and toothpaste slurry. J Clin Periodontol 2001. Apr; 28(4): 325-330.

60. Robinson PG, Deacon SA, Deery C, Heanue M, Walmsley ad, Worthington HV, Glenny AM, Shaw WC: Manual versus powered toothbrushing for oral health. Cochrane Database Syst Rev 2005. Apr. 18.; (2):CD002281. Review.

61. Rosema NA, Timmerman MF, Versteeg Pa, van Palenstein Helderman WH, Van der Velden U, Van der WeiJden Ga: Comparison of the use of different modes of mechanical oral hygiene in prevention of plaque and gingivitis. J Periodontol 2008. Aug; 79(8): 1386-1394.
62. SANGNES G: Traumatization of teeth and gingiva related to habitual tooth cleaning procedures. J Clin Periodontol 1976. May; 3(2): 94-103.

63. SaXer UP, YankelL SL: Impact of improved toothbrushes on dental diseases (II). Quintessence Int 1997; 28, 573-593.

64. Stoltze K, BAY L: Comparison of a manual and a new electric toothbrush for controlling plaque and gingivitis. J Clin Periodontol 1994; 21, 86-90.

65. Terézhalmy GT, Bartizek RD, Biesbrock AR: Relative plaque removal of three toothbrushes in a nine-period crossover study. J Periodontol 2005. Dec; 76(12): 2230-2235.

66. Terezhalmy GT, IfFLand $\mathrm{H}$, Jelepis $\mathrm{C}$, Waskowski J: Clinical evaluation of the effect of an ultrasonic toothbrush on plaque, gingivitis, and gingival bleeding: a six-month study. J Prosthet Dent 1995; 73(1): 97-103.

67. Tinanoff N, Kanellis MJ, Vargas CM: Current understanding of the epidemiology mechanisms, and prevention of dental caries in preschool children. Pediatr Dent 2002. Nov-Dec; 24(6): 543551. Review.

68. Tritten CB, Armitage GC: Comparison of a sonic and a manual toothbrush for efficacy in supragingival plaque removal and reduction of gingivitis. J Clin Periodontol 1996. Jul; 23(7): 641-648.

69. Van der Weijden Ga, Danser M, Niuboer A, Timmermann MF, Van DER VELDEN U: The plaque removing efficacy of a reciproque rotating toothbrush. J Dent Res 1991; 70, 557.

70. Van der Weijden GA, Timmerman MF, NiJboer A, Lie MA, Van der VELDEN U: A comparative study of electric toothbrushes for the effectiveness of plaque removal in relation to toothbrushing duration. Timerstudy. J Clin Periodontol 1993; 20(7): 476-481.

71. Van der Weijden FA, Timmerman MF, Reijerse E, Danser MM, Mantel MS, NiJboer A, Van der Velden U: The long-term effect of an oscillating/rotating electric toothbrush on gingivitis. An 8 month clinical study. J Clin Periodontol 1994; 21, 139-145.

72. Van der Weijden FA, Timmerman MF, Piscaer M, IJzerman Y, WarREN PR, VAN der Velden U: A comparison of the efficacy of a novel electric toothbrush and a manual toothbrush in the treatment of gingivitis. Am J Dent 1998; 11, 23-28.

73. Van der Weijden Ga, Timerman MF, ReiJerse E, Snoek CM, Van DER VELDEN U: Toothbrushing force in relation to plaque removal. $J$ Clin Periodontol 1996; 23, 724-729.

74. Van der Weijden Ga, Timmerman MF, Piscaer M, Snoek I, Van deR VeLden U, Galgut PN: Effectiveness of an electrically active toothbrush in the removal of overnight plaque and treatment of gingivitis. J Clin Periodontol 2002; 29: 699-704.

75. Van der Weijden GA, Timmerman MF, Versteeg PA, Piscaer M, VAN DER VELDEN U: High and low brushing force in relation to efficacy and gingival abrasion. J Clin Periodontol. 2004 Aug; 31(8): 620-624.

76. Versteeg PA, Timmerman MF, Paraskevas S, van der Weijden GA Evaluation of several brushing motion combinations in relation to plaque-removing efficacy with Oral-B CrossAction Power: a professional brushing study. Int J Dent Hyg 2006. Nov; 4(4): 204-208.

77. WarRen PR, Chater BV: An overview of established interdental cleaning methods. J Clin Dent 1996; 7(3 Spec No): 65-69. Review.

78. Warren PR, Chater B: The role of the electric toothbrush in the control of plaque and gingivitis: a review of 5 years clinical experience with the Braun Oral-B Plaque Remover (D7). Am J Dent 1996; 9, 5-11.

79. Williams K, Ferrante A, Dockter K, Haun J, Biesbrock AR, BarTIZEK RD: One- and 3-minute plaque removal by a battery-powered versus a manual toothbrush. $J$ Periodontol 2004. Aug; 75(8): $1107-1113$

80. Zimmer S, Nezhat V, Bizhang M, Seemann R, Barthel C: Clinical efficacy of a new sonic/ultrasonic toothbrush. J Clin Periodontol 2002. Jun; 29(6): 496-500.

81. Zimmer S, Strauss J, Bizhang M, Krage T, Raab WH, Barthel C: Efficacy of the Cybersonic in comparison with the Braun 3D Excel and a manual toothbrush. J Clin Periodontol 2005. Apr; 32(4): 360-363. 
Nagy P, Kövér K, Gera I, Horváth A

Evaluation of the efficacy of powered and manual toothbrushes in preventing oral diseases

(Systematic review with meta-analysis)

Background: The removal of dental plaque plays an essential role in the maintenance of oral health. Numerous powered and manual toothbrushes were manufactured to achieve this goal, but even up to this day different opinions and research results have been revealed to assess the priority of the mentioned devices.

Aim: Comparison of powered and manual toothbrushes on the basis of periodontal parameters and safety.

Materials and methods: Electronic search of the databases of MEDLINE and EMBASE (until May 2014) was carried out with the help of keywords in order to find relevant trials. The inclusion criteria were as follows: randomised controlled clinical trials, adult population, the presence of at least 15 permanent teeth. Split-mouth trials and interventions carried out by dental professionals, were excluded. Primary outcomes were the changes of plaque and gingival indices, while secondary outcomes were probing pocket depth (PPD), safety and quality assessment. The effect-size of the interventions was expressed by the standardised mean difference (SMD) with 95\% confidence interval (CI). Random-effects models were performed.

Results: Electronic search resulted in 173 hits. 21 trials with the total number of 1500 subjects were then eligible for the meta-analysis. Both toothbrushes were safe, without considerable side effects on soft or hard tissues. Powered toothbrushes seemed to be generally more effective in removing plaque $(-9 \%)$, reducing gingivitis $(-6 \%)$ and preventing calculus formation. The SMDs for plaque and gingival indices were $-0,40(95 \% \mathrm{Cl}:-0,95$ to $-0,16)$ and $-0,29(95 \% \mathrm{Cl}$ : $-0,56$ to $-0,03)$ respectively, in favour of the powered devices. There was no significant difference in changes of PPD. By further dividing the powered toothbrushes according to their mode of action, the plaque removal effect of the rotation oscillation (plus three dimensional), side to side sonic and ultrasonic toothbrushes seemed to be significantly better, than their manual ones, while the counter oscillation and the ionic toothbrushes did not perform better. Quality assessment and sensitivity analysis revealed various types of bias up to a certain extent. Consequently, no trial was found to be eligible for the highest quality criteria.

Conclusions: The investigated rotation oscillation and vibrating toothbrushes appeared to be statistically more effective than their manual counterparts, although there is little known about its clinical relevance. The advantage of the electric toothbrushes disappears in case of adequately instructed and motivated patients that highlights the importance of individualised oral hygiene education. The design of the trials shows high heterogeneity, therefore their clinical implications should be handled carefully.

Keywords: powered and manual toothbrush, plaque index, gingival index, systematic review, meta-analysis

\section{5-ben Dr. Vass Zoltán kapta az Orsós Emlékplakett kitüntetést}

Az „Orsós Sándor Baráti Emléktársaság Egyesület” 2001. december 15-én alakult. Alapítói olyan magyar fogorvosok voltak, akik a neves sztomatológus, Dr. Orsós Sándor egyetemi tanár, intézetigazgató közvetlen munkatársai, tisztelői voltak, vagy Orsós professzor szakmai irányítása alatt dolgoztak - többségében vezető beosztásban - az ország különböző helyein. Ezen kollégák azt vállalták, hogy Orsós Sándor emlékét tisztelettel megőrzik és továbbviszik azt a szellemiséget, amelyet Orsós professzor úr életében képviselt.

Az Emléktársaság egyesületként működik. Létszáma jelenleg 26 rendes tagból áll, és vannak örökös, illetve tiszteletbeli tagjai is. A Társaság legfőbb szerve a közgyúlés, amely a társasági törvény szabályai szerint múködik (pl. dönt az új tagok felvételéről).

A közgyúlés évente ülésezik. A 2015. évi közgyűlésre 2015. október 24-én került sor a meghirdetett napirendi pontokkal. A résztvevők száma 20 fő volt. A köz- gyűlés egyhangú szavazással Dr. Vass Zoltán nyugdíjas főorvosnak ítélte oda a 2015. évi „Orsós Emlékplakett” kitüntetést. Az Emlékplakettet a Társaság 2008ban alapította, és egy évben csak egy személynek adható.

Dr. Vass Zoltán a Budapesti Orvostudományi Egyetem Konzerváló Fogászati Klinikájának hosszú éveken át oktatója volt, majd Orsós professzor meghívására az akkori Központi Stomatológiai Intézet főorvosa lett. Kiválóan irányította az országosan jól szervezett protetikus főorvosi hálózat fogorvosait és nagy szerepet vállalt a fogtechnikus képzésben és továbbképzésben. Elévülhetetlen érdemei voltak az Orsós Társaság létrehozásában, az Alapszabály megalkotásában. A Társaság megalakulása óta tagja a Vezetőségnek.

\section{Dr. Orosz Mihály} vezetőségi tag 